\title{
Phytochemistry and Pharmacological Activity of Plants of Genus Curculigo: An Updated Review Since 2013
}

\author{
Ying Wang, Junlong Li and Ning $\mathrm{Li}^{*}$
}

check for

updates

Citation: Wang, Y.; Li, J.; Li, N. Phytochemistry and Pharmacological Activity of Plants of Genus Curculigo: An Updated Review Since 2013.

Molecules 2021, 26, 3396. https:/ / doi.org/10.3390/molecules26113396

Academic Editors: Yasuyoshi Miyata, Won Sup Lee, Dehai Li,

Natthida Weerapreeyakul and

Kittisak Likhitwitayawuid

Received: 24 April 2021

Accepted: 31 May 2021

Published: 3 June 2021

Publisher's Note: MDPI stays neutral with regard to jurisdictional claims in published maps and institutional affiliations.

Copyright: (c) 2021 by the authors. Licensee MDPI, Basel, Switzerland. This article is an open access article distributed under the terms and conditions of the Creative Commons Attribution (CC BY) license (https:// creativecommons.org/licenses/by/ $4.0 /)$.
Inflammation and Immune Mediated Diseases Laboratory of Anhui Province, School of Pharmacy, Anhui Medical University, Hefei 230032, China; m18326039565@163.com (Y.W.); lijunlong3317@gmail.com (J.L.) * Correspondence: 1993500019@ahmu.edu.cn; Tel.: +86-5516-516-1115

Abstract: The genus Curculigo, as a folk herbal medicine, has been used for many years in China, treating impotence, limb limpness, and arthritis of the lumbar and knee joints. The last systematic review of the genus Curculigo was written in 2013, scientifically categorizing the phytochemistry and biological activities. Hitherto, the original compounds and their pharmacological activities were presented as the development of this genus, but there is not an updated review. To conclude the progression of the genus Curculigo, we collected the new literature published from 2013 to 2021 in PubMed, Web of Science, Google Scholar databases, and the Chinese National Knowledge Infrastructure. The novel chlorophenolic glucosides, curculigine, phenolic glycosides, orcinosides and polysaccharides were isolated from Curculigo. The new analyzing methods were established to control the quality of Curculigo as a herbal medicine. In addition, the pharmacological effects of Curculigo focused on anti-diabetes, antibacterial, anti-inflammatory, osteoporosis, antioxidation, etc. The antitumor and neuroprotective activities were newly explored in recent years. The application of herbal medicine was gradually developed in scientific methods. The medicinal value of the genus Curculigo needs to further investigate its pharmacological mechanisms. This new review offers more insights into the exploitation of the pharmacological value of the genus Curculigo.

Keywords: genus Curculigo; phytochemistry; pharmacological activities; herbal medicine

\section{Introduction}

Hypoxidaceae has about nine genera and 200 species, mainly distributed in the southern hemisphere of the Old World and North America. It is a small family of herbaceous perennial monocotyledons. These include leaves, roots or basal, usually with conspicuous parallel veins or folded fan-shaped veins; peanuts on flower stems which have petals in multiples of three, actinomorphic; fruit in capsules or pseudo-berries; plants with tubers or bulbs. Curculigo Gaertner is a small genus in the family of Hypoxidaceae. It includes 17 species and four varieties, and seven of these species (two endemic) are in China [1,2]. Curculigo species are perennial herbs, often with tuberous rhizomes [3]. Some species of genus Curculigo are recorded in traditional or fork herbalism worldwide for their medicinal properties. Curculigo orchioides is native to India and is found everywhere, from sea level to $2300 \mathrm{~m}$ above sea level, especially in rocky areas [4]. In China, Curculigo orchioides has a long history of medicinal use, and its rhizome was considered as a tonic medicine to maintain health energy and nourish the liver and kidney since the Tang Dynasty. C. orchioides was often applied for the treatment of impotence, limb limpness, arthritis of the lumbar and knee joints, and watery diarrhea [5]. In the Ayurvedic Medical System, C. orchioides was applied to treat jaundice, asthma, and urinary and skin diseases [6]. Curculigo capitulata was used as an ethnomedicine to treat the disorders of chronic bronchitis, nephritis and reproductive system inflammation in Dai medicine, Yunnan China [7]. Curculigo breviscapa is used to treat edema in the Guangxi province of China [8]. Curculigo pilosa was the first described aboriginal African species in the Curculigo genus, and it is commonly used as a purgative as well as for the management and treatment of hernias, infertility, diabetes, 
genital infections and sexually transmitted infections in the Yoruba tribe of South-West Nigeria [9]. Curculigo recurvata was used to treat snake bites and arthropod stings in the Congo [10].

The plants of the genus Curculigo contain diverse secondary metabolites with a variety of bio-activities. Up to now, 10 species including C. orchioides, C. capitulata, C. sinensis, C. crassifolia, C. breviscapa, C. gracilis, C. recurvata, C. glabrescens, C. pilosa, and C. latifolia have been chemically and pharmacologically investigated. Previous studies have revealed that phenols and phenolic glucoside, norlignans, and terpenoids were the main consituents in the Curculigo species [11]. These compounds and extracts of Curculigo plants exhibited various bio-activities including adaptive [12], immunomodulation [13], radical scavenging and anti-oxidation [14,15], sweet-tasting and taste-modifying, anti-inflammation [16], aphrodisiac, estrogenic and sexual behavior-modifying [17], neuroprotection [18], antidepression [19-21], nephroprotection [22], anti-osteoporotic [23-25], antiarthritic [26], antitumor [27], mast cell stabilization and antihistaminic [28], and antidiabetic activity [29].

The isolation, structures and bio-activities of the compounds from species belonging to genus Curculigo have been previously reviewed. These monographs $[11,30,31]$ presented the traditional use, phytochemistry, pharmacology and toxicology of plants in the genus Curculigo. However, the phytochemicals of the medicinal plants of genus Curculigo are inadequately reviewed and the related pharmacological advances are not updated. It was only in 2020 that Pradeep Goyal et al. reviewed the morphology, pharmacology and chemical properties of Curculigo orchioides [32]. This current review comprehensively summarizes the latest literature dealing with the isolation, chemical structural elucidation, synthesis and pharmacological activities of the medicinal plants of the genus Curculigo, concentrating on the work that has appeared in the literature from 2013 up to March 2021.

\section{Phytochemistry}

The plants of the genus Curculigo contain diverse secondary metabolites with various biological activities. From 2013 to now, a number of chemical constituents have been isolated from the rhizomes or fruits of the plants of the genus Curculigo. The structure of the monomer compounds was identified by extensive spectroscopic analysis (UV, IR, HRESIMS, 1D and 2DNMR) and single-crystal X-ray diffraction analysis. The constituents of polysaccharides were determined by an ultraviolet-visible spectrophotometer (UV-2550, Shimadzu, Kyoto, Japan). As literature reported, polysaccharides, norlignans, phenolics, and terpenoids are the main bio-active compounds recently found in this genus. The isolation, characterization, chemistry, as well as related bioactivities of these compounds were highlighted in their chemical categorization.

\subsection{Polysaccharides and Monosaccharide}

From the rhizomes of $C$. orchioides, Wang et al. (2017) obtained a water soluble Oacetyl-glucomannan COP90-1 (1) with molecular weight $4609 \mathrm{Da}$, which was composed of $(1 \rightarrow 4)$-linked $\beta$-D-Manp, $(1 \rightarrow 4)$-linked 3-O-acetyl- $\beta$-D-Manp, and $(1 \rightarrow 4)$-linked $\beta$-D-Glcp, $(1,3 \rightarrow 6)$-linked $\beta$-D-Manp, and terminated with $\beta$-D-Manp and $\alpha$-D-Glcp. SEM and Congo red analysis showed that COP90-1 was homogeneous with an inerratic ellipsoid shape instead of triple-helix structure. In vitro, COP90-1 effectively promoted the proliferation and differentiation of primary osteoblasts [33]. Two years later, Wang et al. (2019) isolated and purified a novel homogeneous heteropolysaccharide COP70-3 (2) with a main backbone chain of $(1 \rightarrow 5)$-linked $\alpha$-L-Araf, $(1,3 \rightarrow 5)$-linked $\alpha$-L-Araf, $(1 \rightarrow 6)$-linked $\beta$-D-Galp, $(1 \rightarrow 4)$-linked $\beta$-D-Manp, $(1,2 \rightarrow 5)$-linked $\alpha$-L-Araf, $(1 \rightarrow 3)$-linked $\beta$-L-Rhap, $(1,3 \rightarrow 6)$-linked $\beta$-D-Manp, $(1 \rightarrow 3)$-linked $\alpha$-D-GalpA, $(1,3 \rightarrow 6)$-linked $\beta$-D-Galp and $(1 \rightarrow 6)$-linked $\alpha$-D-Glcp residues. Furthermore, in vitro COP70-3 displayed anti-osteoporosis activity indicated by obvious promotion of the differentiation of MC3T3-E1 cells at $1.87 \mathrm{nM}$, and significantly improved the osteogenic mineralization rate at $0.94 \mathrm{nM}$ and $1.87 \mathrm{nM}$, respectively [34]. Chao Niu et al. used preparative reversed-phase high performance liquid chromatography $\left(\mathrm{MeOH}-\mathrm{H}_{2} \mathrm{O}, 10: 1 \sim 1: 1\right.$, flow rate $2.5 \mathrm{~mL}$ beat $\mathrm{min}$, wavelength $203 \mathrm{~min}$ ) to obtain levoglu- 
cosan (3) [35] (Figure 1). Levoglucosan were obtained from the genus Curculigo for the first time.

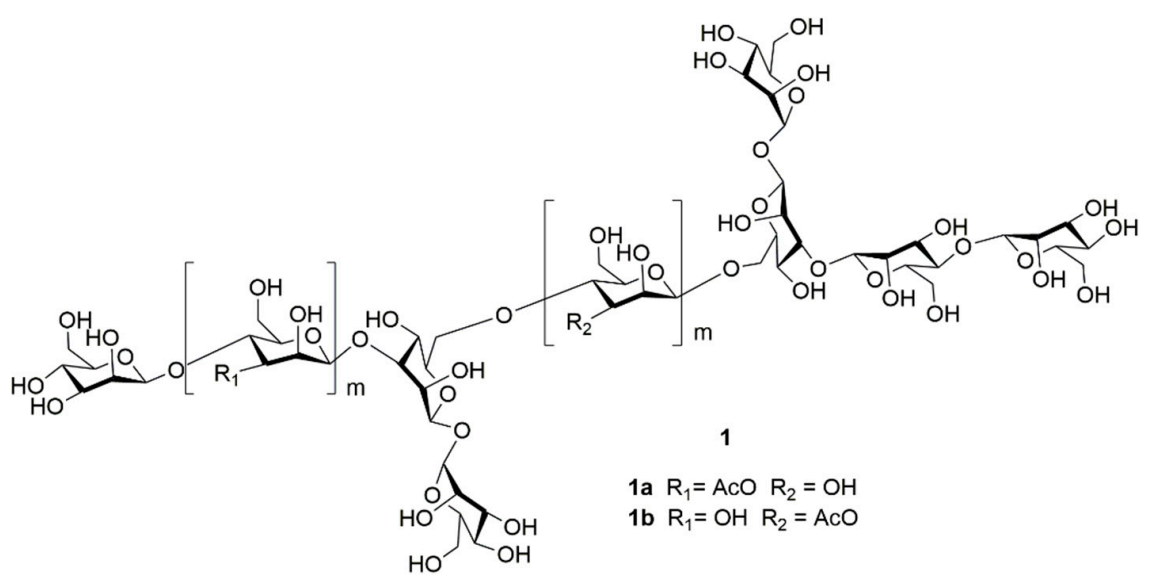

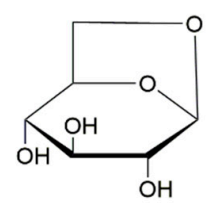

3

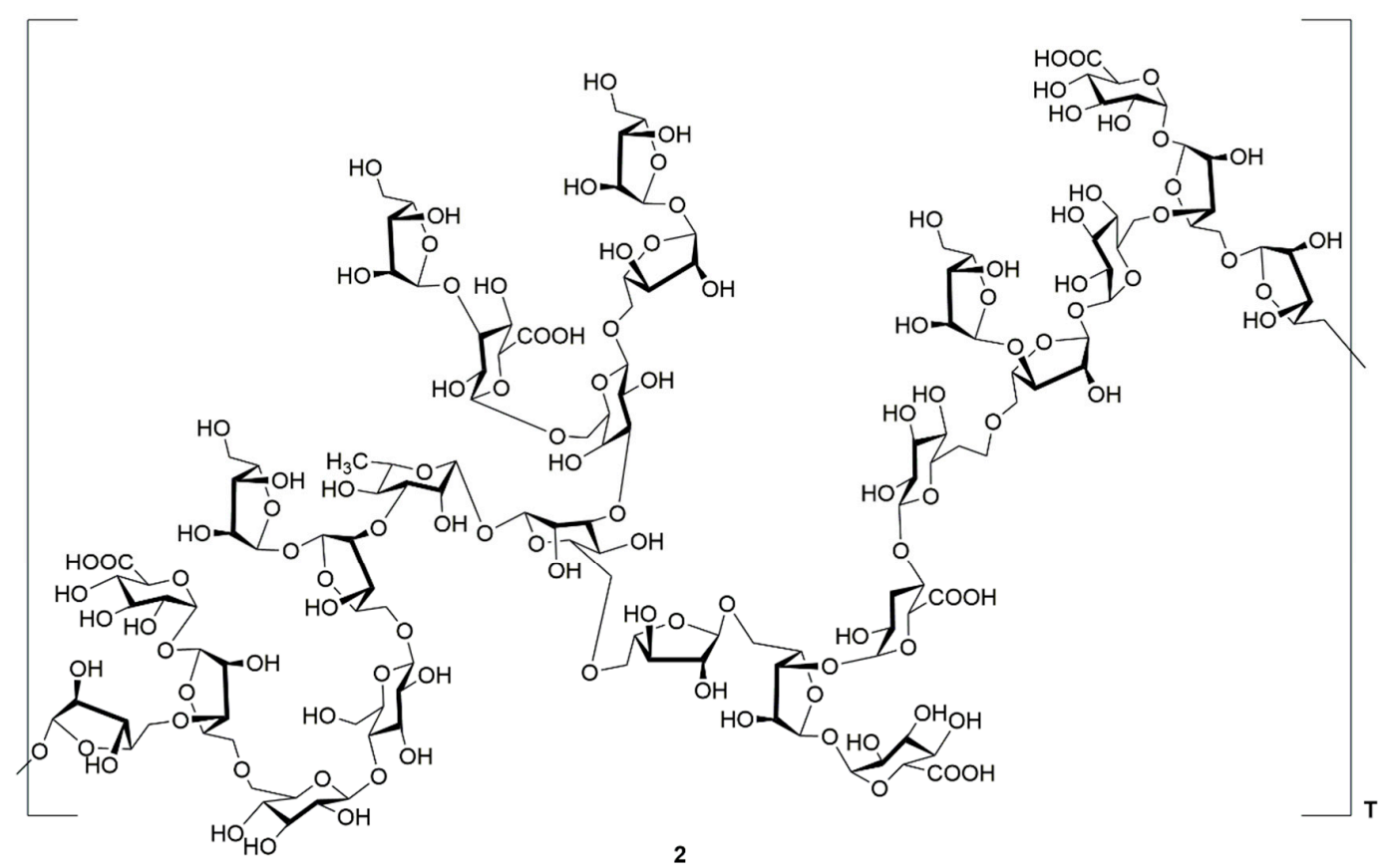

Figure 1. Predicted chemical structures of polysaccharides and monosaccharide (1-3) from the plants of the genus Curculigo.

\subsection{Norlignans}

Norlignans are typical compounds in the plants of section Molineria in the genus Curculigo [15,36-38]. From the roots of Curculigo capitulate, Li et al. (2019) identified three unprecedented 9-norlignans (capitulactones A-C, 4-6) featuring a unique 3,5-dihydrofuro[2,3d]oxepin-7(2H)-one scaffold. Their structures with the absolute configurations were unambiguously established by a combination of spectroscopic data, ECD analysis, and total synthesis. The unique scaffold of the common western hemisphere of the molecules was constructed by using the oxidation-reduction strategy from benzodihydrofuran (Figure 2) [39]. In addition, hypothetical biosynthetic pathways for capitulactones A-C (4-6) were also proposed (Scheme 1). Sinenside A (7) was a norlignan isolated from Curculigo sinensis characterized by a unique cyclic disaccharide (or saccharide dianhydride) in which two pyranose residues are fused with a challenging 1, 2-trans-configuration [38]. Paresh and Chepuri (2015) accomplished the total synthesis of sinenside A (7) in nine steps by using 
an intramolecular acetalization as the key step directly affords the target parent tricyclic ring system (Scheme 2) [40].
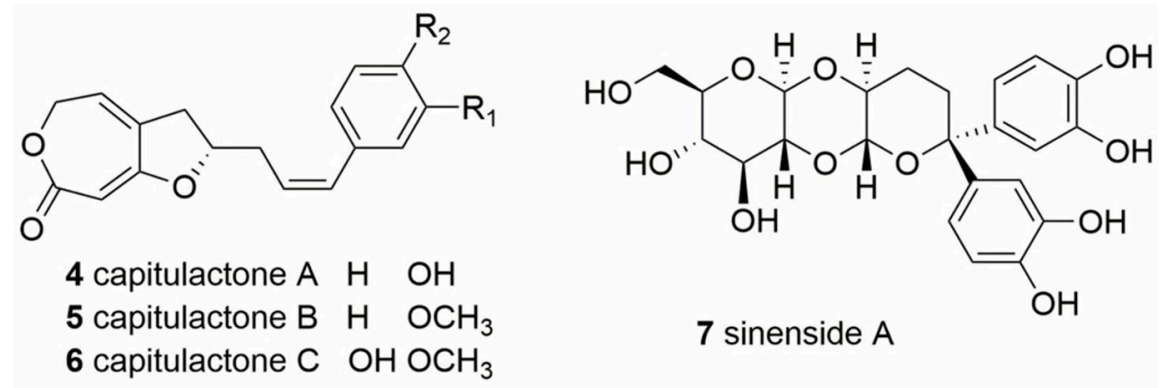

Figure 2. Norlignans (4-7) from the plants of genus Curculigo.<smiles>C=C(C)CC</smiles>

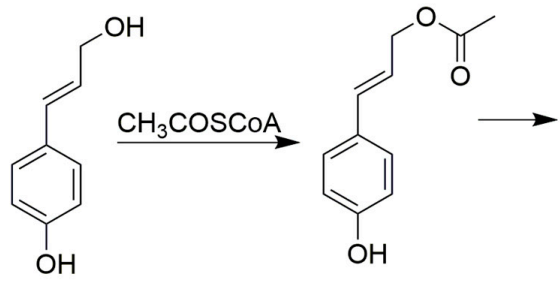<smiles>C=CC=C1C=CC(=O)C=C1</smiles>
p-Coumarate p-Coumarate alcohol

p-Coumarate acetate

Quinonemthide<smiles>O=C(O)C(=Cc1ccc(O)cc1)C(=O)O</smiles>

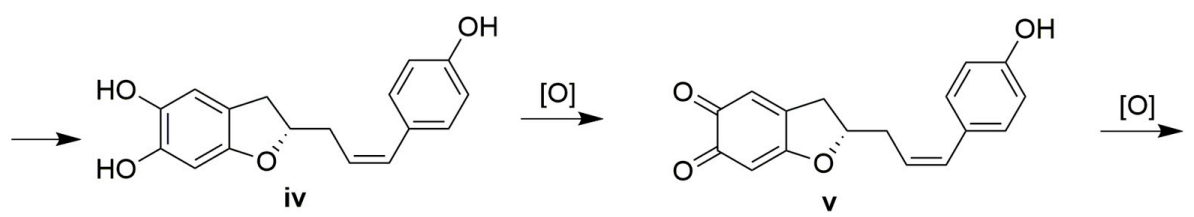

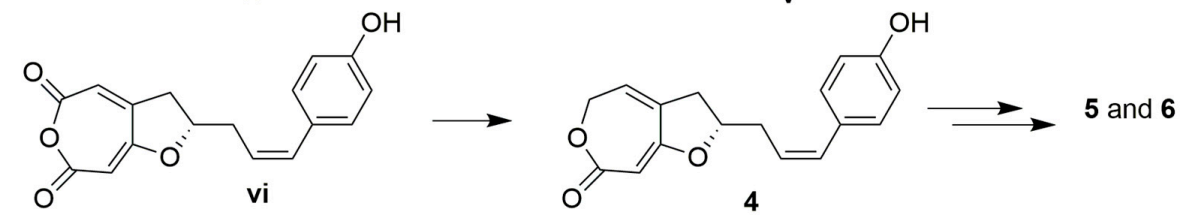

Scheme 1. Proposed hypothetical biosynthetic pathway for capitulactones A-C (4-6).

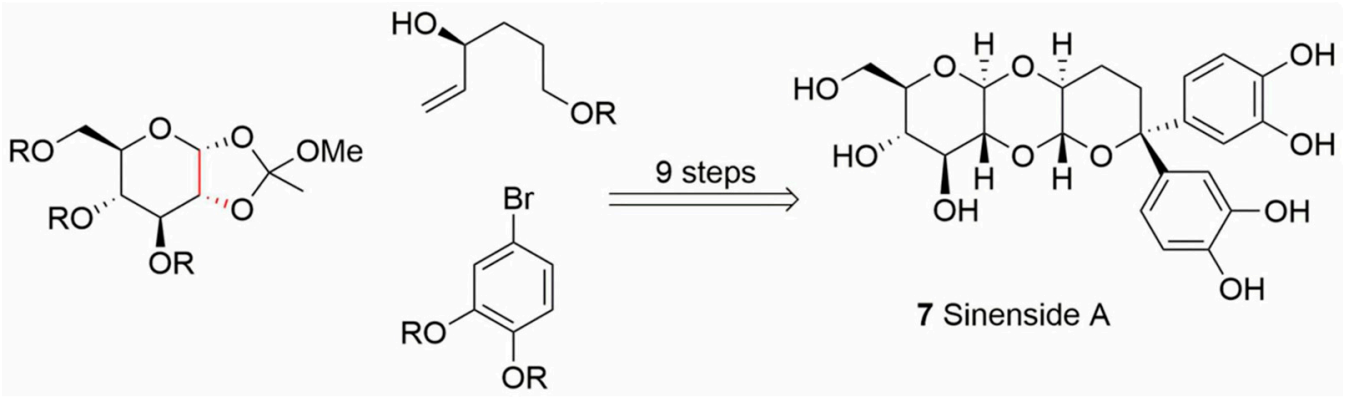

Scheme 2. Total synthesis pathway for Sinenside A (7). 


\subsection{Chlorophenolic Glucosides}

Curculigines are rare natural chlorine-containing compounds occurring in C. orchioides. $\mathrm{Xu}$ and his co-workers reported three chlorophenolic glucosides, $\mathrm{B}$ and $\mathrm{C}$ from the rhizome of C. orchioides in 1987 and 1992 [41,42]; Cao et al. (2009) identified curculigine D [43]. From rhizomes of $C$. orchioides, Wang et al. (2013; 2014; 2018) obtained eleven chlorophenolic glucosides as curculigine $\mathrm{E}-\mathrm{O}$ (8-18). Among them, compounds 8-10, 12, 14-18 showed moderate effects on osteoblast proliferation with a proliferation rate of $10.1 \%-15.9 \%$ in MC3T3-E1 cells. Further structure-activity relationship analysis revealed that anti-osteoporosis activity of chlorophenol glycosides is higher than that of phenolic glycosides. The C-6-linked chlorine in chlorophenol glycosides may reduce their antiosteoporosis activity and the introduction of a C-5 hydroxyl group into the aglycone of chlorophenol glycosides increases their anti-osteoporosis activity [44-46]. Deng et al. (2020) isolated two new chlorophenolic glucosides named curculigine $P$ and $Q(\mathbf{1 9}, \mathbf{2 0})$ from the rhizomes of $C$. orchioides, and compound 19 displayed high inhibitory potential against 5-reductase in a HaCaT-based bioassay [47]. Chen et al. (2017) purified five chlorophenolic glucosides (21-25) from C. orchioides, and all the compounds showed no xanthine oxidase inhibitory activities [48]. In addition, curculigine A (26) was isolated from the same plant and showed no toxicity to human HL-7702 hepatocytes [49]. Chao Niu et al. isolated Orcinol-1-O- $\beta$-D-apiofuranosyl-( $1 \rightarrow 6)$ - $\beta$-D-glucopyranoside (27) and Anacardoside (28) by $\mathrm{CC}$ (ODS, $\mathrm{MeOH}-\mathrm{H}_{2} \mathrm{O}, 1: 5, \mathrm{MeOH}-\mathrm{H}_{2} \mathrm{O}, 1: 1$ ) [35] (Figure 3).<smiles>[R]c1cc(OC(OCC(CO)(CO)C(O)O)C(O)O)c(Cl)c([R])c1Cl</smiles>

$8 \mathrm{R}_{1}=\mathrm{OMe} \mathrm{R}_{2}=\mathrm{Me}$

$9 \mathrm{R}_{1}=\mathrm{Me} \quad \mathrm{R}_{2}=\mathrm{OMe}$<smiles>[R]c1cc(OC(OC(O)C(O)CO)C(O)(CO)CO)c([R])c([R])c1[R]</smiles>

$\begin{array}{lllll}R_{1} & R_{2} & R_{3} & R_{4} & R_{5}\end{array}$

$13 \mathrm{Cl} O \mathrm{Me} \mathrm{Cl} \mathrm{Me} \mathrm{Api}$

$14 \mathrm{Cl} \mathrm{Me} \mathrm{H} O H \quad \mathrm{H}$

$15 \mathrm{H} \mathrm{Me} \mathrm{Cl} \mathrm{OH} \mathrm{H}$<smiles>COc1cc(OC2OC(CO)(CO)C(O)C(O)C2O)cc(C)c1Cl</smiles>

10<smiles>[R]c1cc(OC(OC(O)C(O)C(O)O)C(O)(CO)CO)c(Cl)c([R])c1[R]</smiles>

$\begin{array}{rlll} & \mathrm{R}_{1} & \mathrm{R}_{2} & \mathrm{R}_{3} \\ 16 \mathrm{OH} & \mathrm{Cl} & \mathrm{Me} \\ 17 \mathrm{Me} & \mathrm{Cl} & \mathrm{OH} \\ 18 \mathrm{Me} & \mathrm{H} & \mathrm{OMe}\end{array}$<smiles>[R2][R]([H])=C([R2])[R]</smiles><smiles>[R]CC(O)(CO)C(O)C(O)C(O)CO</smiles>

$\begin{array}{llll}R_{1} & R_{2} & R_{3} & R_{4}\end{array}$

$19 \mathrm{Cl} \mathrm{OMe} \mathrm{H} \mathrm{Me}$

$20 \mathrm{OMe} \mathrm{Me} \mathrm{Cl} \mathrm{OMe}$

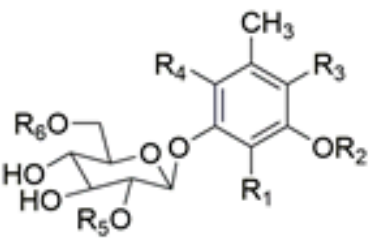

$\begin{array}{lllllll} & \mathrm{R}_{1} & \mathrm{R}_{2} & \mathrm{R}_{3} & \mathrm{R}_{4} & \mathrm{R}_{5} & \mathrm{R}_{6} \\ \mathbf{2 1} \mathrm{Cl} & \mathrm{H} & \mathrm{H} & \mathrm{H} & \mathrm{H} & \mathrm{H} \\ \mathbf{2 2} \mathrm{H} & \mathrm{H} & \mathrm{Cl} & \mathrm{H} & \mathrm{Api} & \mathrm{H} \\ \mathbf{2 3} \mathrm{Cl} & \mathrm{H} & \mathrm{Cl} & \mathrm{H} & \mathrm{H} & \mathrm{Glc} \\ \mathbf{2 4} \mathrm{Cl} & \mathrm{Me} & \mathrm{Cl} & \mathrm{H} & \mathrm{H} & \mathrm{Glc} \\ \mathbf{2 5} \mathrm{Cl} & \mathrm{Me} & \mathrm{Cl} & \mathrm{OMe} & \mathrm{H} & \mathrm{Glc}\end{array}$

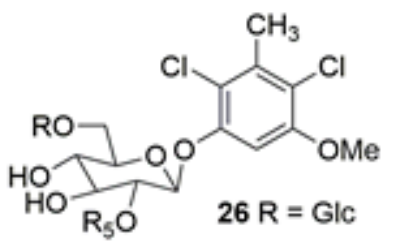<smiles>Cc1cc(O)cc(OC(O)C(O)C(O)CO)c1</smiles>

$27 \mathrm{R}=\mathrm{O}-\beta-\mathrm{D}-$ apiofuranosyl

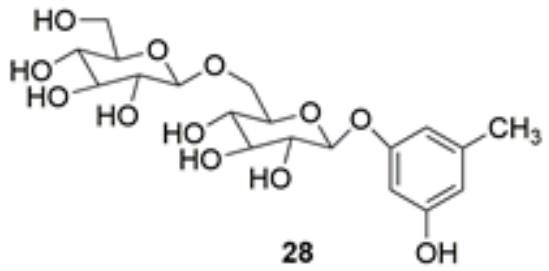

Figure 3. Chlorophenolic glucosides (8-28) from the plants of the genus Curculigo. 


\subsection{Phenolic Compounds}

Phenolic compounds are the main metabolites occurring in the plants of the genus Curculigo. From the rhizomes of C. orchioides, Wang et al. (2013; 2014) obtained two new phenolic glucosides, orcinoside $\mathrm{H}$ (29) and curculigoside I (42), together with ten known ones as orcinol glucoside (30), orcinol glucoside B (31), curculigoside A (32), curculigoside B (33), curculigoside C (34), curculigoside G (35), 3-hydroxy-5-methylphenol-1$O$-[ $\beta$-glucopyranosyl-(1-6)- $\beta$-D-glucopyranoside] (36), 3-hydrox-5-methyl-phenol-1-O-[ $\beta$ apiosyl-(1-6)- $\beta$-glucopyranoside] (37), glucosyringic acid (39), and benzyl-O- $\beta$-D-glucopyranoside (40). Among them, compounds 30, 31, 34, 39, and 42 showed weak anti-osteoporotic activity [44,45]. Jiao et al. (2013) isolated orcinol glucoside (30), curculigoside B (33) and glucosyringic acid (39) from rhizomes of $C$. orchioides, and all of these three have no hepatotoxicity against the human hepatic cell line HL-7702 [49]. Chen et al. (2017) reported two new heterocyclic phenolic derivatives, orcinosides I and J (44 and 45), together with four known phenolic compounds as 3-(4-hydroxy-3-methoxy-phenyl) propane-1,2-diol (46), 3-(4-Hydroxy-3,5-dimeth- oxyphenyl) propane-1,2-diol (47), piperoside (48), 4-ally-2, and 6-dimeoxy phenol glucoside (49). Among them, orcinosides I (44) and J (45) exhibited xanthine oxidase inhibitory activities with the inhibitor rates of $72.40 \pm 4.47 \%$ and $36.71 \pm 3.67 \%$ at the concentrations of $0.55 \mathrm{mM}$. The $\mathrm{IC}_{50}$ of $\mathbf{4 4}$ and 45 were 0.25 and $0.62 \mathrm{mM}$, respectively (Figure 4) [48]. The other two phenolic compounds, named $p$-Hydroxycinnamic acid (51) and 3,5-Dihydroxy-4-methoxybenzoic acid (50) were also isolated from dried and powdered rhizomes of curculigo by Chao Niu et al. In addition, the phenolic compounds were also isolated from dried and powdered curcuma rhizomes by Chao Niu et al. [35]. Compounds $\mathbf{5 0}$ and $\mathbf{5 1}$ were obtained from the genus Curculigo for the first time.

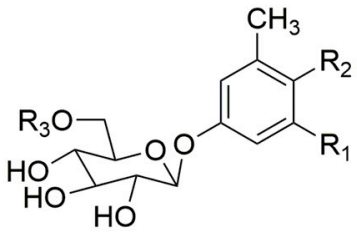

$29 \mathrm{R}_{1}=\mathrm{Me} \mathrm{R}_{2}=\mathrm{H} \mathrm{R} \mathrm{R}_{3}=\mathrm{H}$ $30 \mathrm{R}_{1}=\mathrm{OH} \mathrm{R}_{2}=\mathrm{H} \mathrm{R}_{3}=\mathrm{H}$ $31 \mathrm{R}_{1}=\mathrm{OH} \mathrm{R} \mathrm{R}_{2}=\mathrm{H} \mathrm{R}_{3}=\mathrm{COCH}_{3}$<smiles>[R]c1ccc(COC(=O)c2c(OC)ccc([R8])c2[R])c(OC2OC(CO)(CO)C(O)C(O)C2O)c1</smiles>

$32 \mathrm{R}_{1}=\mathrm{OH} \mathrm{R}_{2}=\mathrm{OMe} \mathrm{R}_{3}=\mathrm{H}$ $33 \mathrm{R}_{1}=\mathrm{OH} \quad \mathrm{R}_{2}=\mathrm{OH} \quad \mathrm{R}_{3}=\mathrm{H}$ $34 \mathrm{R}_{1}=\mathrm{OH} \mathrm{R}_{2}=\mathrm{OMe} \mathrm{R}_{3}=\mathrm{OH}$ $35 \mathrm{R}_{1}=\mathrm{H} \quad \mathrm{R}_{2}=$ OMe $\mathrm{R}_{3}=\mathrm{H}$

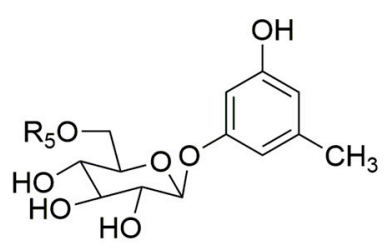

$36 \mathrm{R}=\mathrm{H}$

$37 \mathrm{R}=\mathrm{Api}$

$38 \mathrm{R}=\mathrm{Glc}$<smiles>[R]Oc1cc(C(=O)O)cc(OC)c1OC</smiles>

$39 \mathrm{R}=\mathrm{H}$

$40 \mathrm{R}=\mathrm{GlC}$<smiles>[R9]CC(O)(CO)C(O)C(O)C(O)OCc1ccccc1</smiles>

$41 \mathrm{R}=\mathrm{H}$

$42 \mathrm{R}=\mathrm{Api}$<smiles>COc1cccc(OC)c1COC1OCC(O)C(O)(CO)OCC1O</smiles>

43

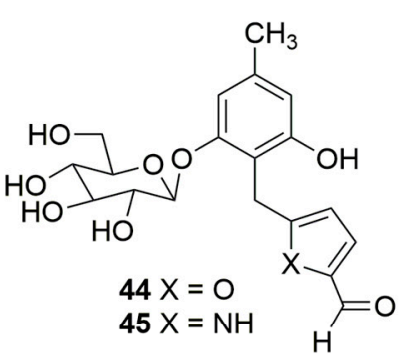<smiles>[R20]c1cc(CC(O)CO)cc(OC)c1[R20]</smiles>

$46 \mathrm{R}_{1}=\mathrm{H} \quad \mathrm{R}_{2}=\mathrm{H}$

$47 \mathrm{R}_{1}=\mathrm{OMe} \mathrm{R}_{2}=\mathrm{H}$

$48 \mathrm{R}_{1}=\mathrm{H} \quad \mathrm{R}_{2}=\mathrm{Glc}$

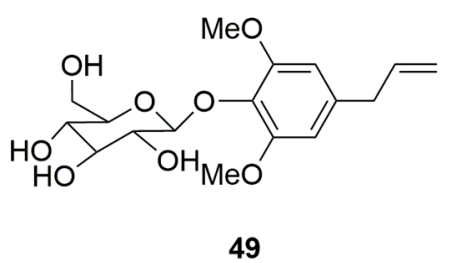<smiles>COc1c(O)cc(C(=O)O)cc1O</smiles>

50<smiles>O=C(O)/C=C/c1ccc(O)cc1</smiles>

51

Figure 4. Phenolic compounds (29-51) from the plants of the genus Curculigo. 


\subsection{Terpenoids}

Terpenoids are a small class of second metabolites found in Curculigo species. From the rhizomes of $C$. orchioides, a new cycloartane-type triterpenoid ketone (52) was isolated [49], and 52 showed hepatotoxicity against the human hepatic cell line HL-7702 in vitro. Zhang et al. (2019) obtained six terpenoids from $C$. orchioides as (3S,5R,6S,7E,9R)megatigma-7-ene-3,5,6,9-tetrol (53), actinidioionoside (54), (6S,9R)-roseoside (55), (-)angelicoidenol-2- $O$ - $\beta$-D-glucopyranoside (56), (-)-angelicoidenol-2- $O-\beta$-apiofuranosyl$(1 \rightarrow 6)$ - $\beta$-D-gluco-pyranoside (57), tetillapyrone [(7R,9S,10R)-3-methyl-5-(4-hydroxyl-5hydroxylmethyl-tetrahydrofuryl)]-6-hydroxypyran-2-one (58) (Figure 5) [25].

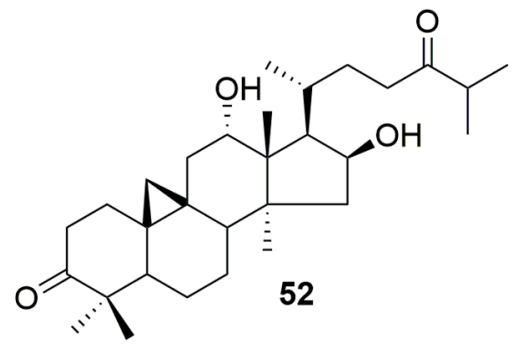<smiles>[R20]OC(C)/C=C/[C@@]1(O)[C@H](C)C[C@@H]([R20])CC1(C)C</smiles>

$$
\begin{array}{ll}
53 R_{1}=H & R_{2}=H \\
54 R_{1}=H & R_{2}=G l c
\end{array}
$$

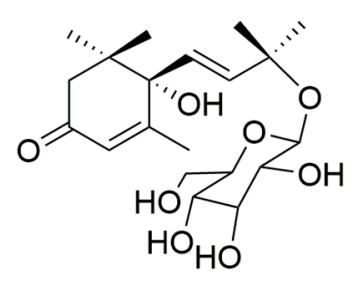

55

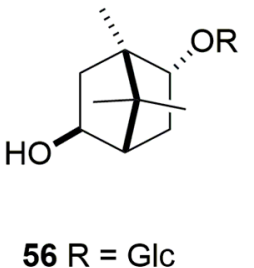

$57 \mathrm{R}=\mathrm{GlC}-\mathrm{Api}$<smiles>Cc1cc(C2CC(O)C(CO)O2)c(O)oc1=O</smiles>

58

Figure 5. Terpenoids (52-58) from the plants of the genus Curculigo.

\subsection{Cyclic Peptides}

Besides the above compounds, Chen et al. (2017) yielded eight known cyclodipeotides as cyclo-(L-Ala-L-Tyr) (59), cyclo-(L-Ser-L-Phe) (60), cyclo-(LeuAla) (61), cyclo-(Leu-Thr) (62), cyclo-(Leu-Ser) (63), cyclo-(S-Pro-R-Leu) (64), cyclo-(Val-Ala) (65) and cyclo-(Gly-DVal) (66) were obtained from the rhizomes of $C$. orchioides (Figure 6) [48].<smiles>CC1NC(=O)C(Cc2ccc(O)cc2)NC1=O</smiles>

59<smiles>CC(C)CC1NC(=O)C(CO)NC1=O</smiles>

63<smiles>O=C1N[C@H](CO)C(=O)NC1Cc1ccccc1</smiles>

60<smiles>CC(C)C[C@]1(C)NC(=O)[C@@H]2CCCN2C1=O</smiles>

64<smiles>CC(C)CC1NC(=O)C(C(C)O)NC1=O</smiles>

61<smiles>CC1NC(=O)C(C(C)C)NC1=O</smiles>

65<smiles>CC(C)CC1NC(=O)C(C)NC1=O</smiles>

62<smiles>CC(C)C1NC(=O)CNC1=O</smiles>

66

Figure 6. Cyclic peptides (59-66) from the plants of the genus Curculigo. 


\section{Pharmacological Properties}

Since 2013, there have been a lot of studies and explorations on the pharmacological effects of the genus Curculigo, which have been classified into 12 parts: Anti-Diabetic Activity, Anti-Osteoporosis, Antioxidant, Neuroprotective Effect, Antitumor, Antibacteria, Anti-Inflammation and Anti-Arthritis, Anti-Diarrhea and Anti-Nociception, Effect on Perimenopausal Syndrome, Male Reproductive Improvement, Cardio-Protection, Other Activities. All of this was summarized in "Table 1".

\subsection{Anti-Diabetic Activity}

Karigidi et al. (2020) reported that Curculigo pilosa supplemented (CPS) diet and significantly lowered the blood glucose in streptozotocin (STZ) induced diabetic rats. A CPS-diet significantly enhanced the activities of hepatic glycolytic and lowered the gluconeogenic enzymes in diabetic animals. A CPS-diet also restored the lipid profile, oxidative stress markers and serum markers of hepatic and renal damages in the diabetic rats [50]. In another experiment conducted by Karigidi and Olaiya (2020), oral administration of an extract of C. pilosa effectively mitigated the hyperglycemia mediated oxidative damage via improving the antioxidant system to inhibit the generation of lipid peroxide, hydrogen and nitric oxide [51]. Moreover, an extract of Curculigo pilosa also demonstrated a strong ability to inhibit biomarker enzymes [52]. The fruits and root aqueous extract of Curculigo latifolia exerted antidiabetic and hypolipidemic effects through altering regulation genes in glucose and lipid metabolisms in STZ-induced diabetic rats, indicated by an increase in body weight, high density lipoprotein (HDL), insulin, and adiponectin levels, and a decrease in glucose, total cholesterol (TC), triglycerides (TG), low density lipoprotein (LDL), urea, creatinine, ALT, and GGT levels [53]. Singla et al. (2020) found that hydroalcoholic and ethanolic extracts of $C$. orchiodies at doses of 150,300 and $600 \mathrm{mg} / \mathrm{kg}$ significantly attenuated a hyperglycemia induced increase in lipid profile, oxidative stress and normalized the damaged renal functions (albumin, urea and creatinine) in STZ-nicotinamide induced diabetic nephropathy rats [22]. The study by Gulati et al. (2015) showed that ethanolic extract of $C$. orchioides exerted anti-diabetic activity and enhanced glucose uptake in murine 3T3-L1 adipocytes, and inhibited adipogenesis in a cell-based assay [54].

\subsection{Anti-Osteoporosis}

Osteoporosis is a common bone disease characterized by increasing osseous fragility and fracture due to the reduced boss mass and micro-structural degradation. The main strategies for osteoporosis are hormone replacement treatment (HRT) and alendronate therapies that may produce adverse side-effects [55]. The rhizome of $C$. orchioides and related traditional Chinese medicine formulas with strengthening of tendons and bone functions, such as "Er-Xian-Tang", were widely used to prevent and treat osteoporosis [56]. Network pharmacology analysis of active components in C. orchioides targeting osteoporosis predicted that curculigoside (32) and other compounds had therapy potentials for osteoporosis [57-59]. Shen et al. (2013) reported that $100 \mu \mathrm{M}$ curculigoside significantly enhanced the proliferation of bone marrow stromal cells (BMSCs), increased the osteogenic gene expression, and profoundly up-regulated the secretion of osteoprotegerin (OPG) [60]. In the study by Liu et al. (2014), curculigoside (32) from C. orchioides stimulated alkaline phosphatase (ALP) activity and calcium deposition of human amniotic fluidderived stem cells (hAFSCs) during osteogenic differentiation in a dose-dependent manner $(1-100 \mu \mathrm{g} / \mathrm{mL}$ ), and increased the gene expression of osteogenic osteopontin (OPN) and collagen I, inhibiting the osteoclastogenesis through the Wnt/ $\beta$-catenin signal transduction pathway [23]. Zhu et al. (2015) reported that curculigoside (32) was reported to exert anti-osteoporosis activity via regulated proliferation, differentiation and inhibiting of the levels of pro-inflammatory cytokines TNF- $\alpha$, IL-1 $\beta$, IL- 6 and COX-2 in dexamethasoneinduced rat calvarial osteoblasts [16]. In vivo, curculigoside can also promote the calcium deposition of osteoblasts under oxidative stress, increase the levels of ALP and Runx2, and reduce the production and deposition of $A \beta$-induced osteoclasts through antioxidation in 
APP/PS1 mutated mransgenic mice [61]. In the study conducted by Zhang et al. (2019), curculigoside (32) was reported to prevent excess-iron-induced bone loss in mice and osteoblastic MC3T3-E1 cells through anti-oxidation and inhibiting excess-iron- induced phosphorylation of the Akt-FoxO1 pathway that target the genes of MnSOD, Gadd45a, Bim, FasL, and Rab7 [24].

Beside the curculigoside (32), other compounds with anti-osteoporosis obtained from the plants of genus Curculigo activity were also documented. From the rhizomes of $C$. orchioides, Wang et al. $(2017,2019)$ isolated two polysaccharides as COP90-1 (1) and COP703 (2), and both 1 and 2 displayed anti-osteoporosis activities in vitro [33,34]. Wang et al. (2013; 2014; 2018) reported that nine chlorophenolic glucosides, curculigine E-G, I, and $\mathrm{K}-\mathrm{O}(8-10,12$ and 14-18), displayed anti-osteoporosis by increasing the proliferation rate by $10.1 \%-15.9 \%$ in MC3T3-E1 cells [44-46].

\subsection{Antioxidant}

Excessive oxidative stress may cause severe damage to proteins, lipids, DNA, and may even result in cell death and trigger many diseases, such as cancer, cardiovascular disease, diabetes mellitus, and the aging process, etc. [62]. The ethanol extract of $C$. orchioides rhizomes $(1-25 \mu \mathrm{g} / \mathrm{mL})$ showed the high antioxidant activity on superoxide anion radicals, hydroxyl radicals, hydrogen peroxide and DPPH free radicals, and lipid peroxidation in a concentration-dependent manner, and protected from cisplatin-induced auditory damage by inhibiting lipid peroxidation and scavenging activities against free radicals at a concentration range of $2.5-25 \mu \mathrm{g} / \mathrm{mL}$ [63]. Phytochemical profile analysis revealed that orcinol- $\beta$-D-glucoside (30) and curculigoside A (32) were the main antioxidant compounds in C. orchioides [64]. Murali and Kuttan (2015) reported that methanolic extract of $C$. orchioides enhanced the cancer chemotherapeutic efficacy of cyclophosphamide in mice, and had ameliorative effects on cyclophosphamide-induced oxidative stress by lowering the level of lipid peroxidation [65]. The extract of $C$. orchioides restored levels of anti-oxidant enzymes of SOD, CAT, and GST, and significantly decreased the lipid peroxidation in the rat liver induced by Chromium (VI) treatment [66]. In the experiments performed by Hejazi et al. (2018), the ethylacetate fraction (EA) of C. orchioides exhibited significant radical scavenging activity on a DPPH assay with the $\mathrm{IC}_{50}$ as $52.93 \mu \mathrm{g} / \mathrm{mL} ; C$. orchioides also refurbished the anti-oxidant enzyme defense of mammalian tissue during oxidative stress. EA and aqueous ethylacetate (AEA) fraction effectively inhibited the growth of tumor cell lines of HepG2, HeLa and MCF-7, down-regulated the levels of antiapoptotic Bcl-2 expression, and up-regulated the expression of apoptotic proteins caspase-3 and caspase-8 through an intrinsic ROS-mediated mitochondrial dysfunction pathway [67].

Curculigo pilosa, also called Africa crocus, is a folklore diet-medicine in Nigeria. The aqueous extract of $C$. pilosa seeds significantly inhibit the lipid peroxidation of rat penile homogenate induced by $\mathrm{FeSO} 4$ and SNP [68]. The extract of $C$. pilosa effectively mitigated the hyperglycemia mediated oxidative damage via improving the antioxidant system to inhibit the generation of lipid peroxide, hydrogen and nitric oxide in STZ-induced diabetic rats [51]. Ruzu herbal bitters (RHB), an anti-obesity medicinal concoction in Nigeria, mainly made from the root of C. pilosa, significantly increased the activity of peroxidase, CAT and GSH in the liver and brain in high-fat diet induced diabetic rats [69]. For C. latifolia, the extract of the tuber displayed higher antioxidant activity than that of a leaf in a DPPH scavenging assay and a superoxide dismutase assay [70]. The subcritical water extraction of C. latifolia roots displayed significant antioxidant activity in DPPH and ABTS assays, and further LC-MS analysis revealed that phenolic compounds such as monobenzone, hydroquinone, phloridzin, pomiferin, mundulone, scandenin, and dimethyl caffeic acid were the main active compounds [71].

\subsection{Neuroprotective Effect}

The extract of $C$. orchioides rhizome exhibited significant inhibitory effects on acetylcholinesterase, which suggested the potential of $C$. orchioides for the treatment of Alzheimer's 
disease [72] G.K. Pratap et al. used bio-autograph and spectrophotometry to determine the anti-acetylcholinesterase activity of methanol extracts of $C$. orchioides in vitro. The experiment showed that the ethanol extract had a good inhibitory effect on the AChE enzyme. This may help to explain the role of methanol extract from rhizome as an antiacetylcholinesterase drug in the treatment of Alzheimer's disease [73]. The curculigoside (32) in C. orchioides can effectively improve the behavior of Alzheimer's rats, reduce the damage of hippocampal neurons, and inhibit the apoptosis of hippocampal neurons [74]. Dipica Ramchandani et al. induced neurotoxicity in mice with cyclophosphamide. According to the experimental results, it was inferred that the neuroprotective effect of $C$. orchioides may be due to flavonoids and polyphenols [75]. Recently, the antidepressant effects of curculigoside were reported, and related research revealed that curculigoside (32) improved depression-like behavior in mice, and significantly up-regulated the levels of BDNF protein, as well as the concentrations of DA, NE and 5-HT in the hippocampus of depressive animals [76,77]. In vitro, curculigoside A showed the potential for neurovascular repair therapy for stroke and brain injury by modulating the angiogenesis in cerebral endothelial cells via VCAM-1/Egr-3/CREB/VEGF signaling [78]. In vivo, curculigoside A alleviated the cerebral ischemia and reperfusion injury in the middle cerebral artery occluded (MCAO) model rats, induced the cell proliferation and angiogenesis through the Wnt $5 \mathrm{a} / \beta$-catenin and VEGF/CREB /Egr-3/VCAM-1 signaling axis, and promoted the maturation and stability of new blood vessels via increasing Ang1 and Tie-2 expression [79]. In addition, curculigoside exhibited evident neuro-protective effects against N-methyl-Daspartate (NMDA) induced neuronal excitoxicity by prevented NMDA-induced neuronal cell loss, and reduced the number of apoptotic and necrotic cells [80].

Ge et al. (2014) described that orcinol glucoside (OG, 30) improved the depressive behavior of CUMS rats by down-regulating the over-activity of HPA axis and increasing the expression of BDNF and phosphorylation of ERK1/2 in the hippocampus [19]. In another study performed by Wang et al. (2016), it was revealed that OG effectively alleviated anxiety-like behaviors in mice in three different tests, while it had no sedative effects on the animals [76].

Crassifoside $\mathrm{H}(\mathrm{CH})$ is a chlorine-containing norlignan obtained from Curculigo glabrescens. Zhang et al. (2017) reported that $\mathrm{CH}$ effectively improves the depressionlike behavior of CUMS rats, improved HPA axis hyperactivity, reduced plasma CORT and CRH expression in hypothalamus, reversed CUMS-induced decrease of 5-HT1A receptor expression, and up-regulated BDNF and phosphorylated-ERK1/2 levels in the hippocampus [21]. Recent work by Li et al. (2020) revealed that $\mathrm{CH}$ not only alleviated the HPA axis dysfunction in CUMS-induced depressive mice, but also the suppressed expression of inflammatory cytokines of TNF- $\alpha$ and IL- $1 \beta$, as well as the inhibition of NLRP3 inflammasome activation in the hippocampus [81].

\subsection{Antitumor}

Polysaccharides from C. orchioides displayed obvious anti-tumor effects on cervical cancer in mice, and significantly enhanced immune function and induction of apoptosis, indicated by an increase in the thymus and spleen index. Moreover, the polysaccharides significantly up-regulated the expression of caspase-3, caspase-9 and p53 protein in HeLa cells in vitro [27]. The silver nanoparticles (CoBAgNPs) prepared from C. orchioides rhizome extracts in vitro showed an inhibitory effect against human breast cancer cell lines (MDA-MB-231) and Vero cell lines with the $\mathrm{IC}_{50}$ values as $18.86 \mu \mathrm{g} / \mathrm{mL}$ and $42.43 \mu \mathrm{g} / \mathrm{mL}$, respectively [82]. In another study conducted by Selvaraj and Agastian (2017), the ethyl acetate extract and silver nanoparticles $(80 \mu \mathrm{g} / \mathrm{mL})$ synthesized from C. orchioides exhibited maximum growth inhibitory effects against human breast cancer cells (MCF-7) with a rate of $66.12 \%$ and $71.28 \%$ [83].

Murali and Kuttan (2016) reported that the phenolic glucoside curculigoside (32) enhanced the natural killer (NK) cell activity, antibody-dependent cell-mediated cytotoxicity and complement-mediated cytotoxicity in B16F10 melanoma cancer-cell-bearing mice [84]. 
In addition, compound 32 also significantly increased the levels of TH1 cytokines IL-2 and IFN- $\gamma$, reduced the formation of pulmonary metastatic colonies and prolonged the life span of experimental animals. Orcinol glucoside $(O G, 30)$ is another main phenolic glucoside in the rhizomes of $C$. orchioides. Nahak et al. (2018) reported that OG loaded nanostructured lipid carriers (NLC) coated with PEG-25/55-SA exhibited enhanced anticancer activity in gastric, colorectal and hepatocellular carcinoma in vitro [85].

Xiaoyu Wang et al. introduced that Erxian decoction, a traditional Chinese medicine containing $C$. orchioides, can inhibit the metastasis and invasion of ovarian cancer in vivo and in vitro through EGFR, ErbB, MMP2, MMP7, MMP9 and VEGFR [86].

\subsection{Antibacteria}

Marasini et al. (2015) reported that the alcohol extract of C. orchioides had high antibacterial activity against methicillin-resistant Pseudomonas aeruginosa, with the MIC value as $49 \mu \mathrm{g} / \mathrm{mL}$, whereas it had no effect against gram-negative bacteria [87]. Perumal et al. (2017) prepared silver nanoparticles (AgNPs) from C. orchioides leaf extracts, and the phytochemical loaded-silver nanoparticles of $C$. orchioides showed good inhibitory activities against $P$. aeruginosa and S. aureus, with lower activities towards E. coli and K. pneumonia [88]. D. C. Nwokonkwo analyzed the phytochemical composition and antibacterial activities of fresh rhizome powder of Curculigo pilosa. The results showed that the minimum inhibitory concentrations ((MIC)) of crude ethanol extract and neutral metabolites were $25 \mathrm{mg} / \mathrm{mL}$, $50 \mathrm{mg} / \mathrm{mL}$ and $100 \mathrm{mg} / \mathrm{mL}$, respectively [89]. Mohammad Shah Hafez Kabir et al. found that the maximum inhibitory range of methanol extract from C. recurvata to Bacillus cereus was $10.50 \pm 0.5 \mathrm{~mm}$ [90]. Tianyan Yun et al. found newly isolated extracts from medicinal plants (Curculigo Capulata) showed high antifungal activity against Foc TR4. At the same time, the optimization method of fermentation broth was established, and the bacteriostatic activity was increased by $72.13 \%$ [91].

\subsection{Anti-Inflammation and Anti-Arthritis}

Curculigoside A (32), the main active compound in C. orchioides, significantly relieved the hind paw swelling and arthritis index, reduced the serum pro-inflammatory factor levels of IL-6 IL-1 $\beta$, PGE2 and TNF- $\alpha$, decreased MDA and increased SOD activity in serum, and effectively down-regulated the expression of the NF-KB/NLRP3 pathway in Freund's complete adjuvant (FCA) induced adjuvant arthritis rats [92]. In another arthritis rat model induced by type II collagen, compound 32 inhibited paw swelling and arthritis scores, decreased serum pro-inflammatory factor levels of TNF- $\alpha$, IL-1 $\beta$, IL-6, IL-10, IL-12 and IL-17A, down-regulated the expression of JAK1, JAK3 and STAT3, and up-regulated NF- $\mathrm{BB}$ p65 and IкB [26]. Moreover, the anti-arthritis activity of curculigoside A (32) was further confirmed by network pharmacological analysis [57].

\subsection{Anti-Diarrhea and Anti-Nociception}

Ahmad et al. (2020) reported that methanol extracts of $C$. recurvate had significant peripheral anti-nociception effects $(400 \mathrm{mg} / \mathrm{kg} \cdot \mathrm{bw})$ by inhibiting both early and late phases of nociception in the formalin-induced writhing test. In the castor oil-induced diarrhea model, C. recurvate extract significantly prolonged the onset time of diarrhea, reduced the volume and weight of intestinal contents in mice, and significantly decreased gastrointestinal motility. Further in silico molecular docking analysis showed that curculigine and isocurculigine possessed the highest affinity for COX-1 and COX-2; isocurculigine was identified as the most effective anti-diarrheal compound [93].

\subsection{Effect on Perimenopausal Syndrome}

The total glucosides of $C$. orchioides (TGC) showed a therapeutic effect on perimenopause model mice by increasing the index of thymus, uterus and spleen (TI, UI, $\mathrm{SI})$, testosterone $(\mathrm{T})$ and estradiol $\left(\mathrm{E}_{2}\right)$, and reducing the level of luteinizing hormone (LH) $[94,95]$. Curculigoside improved the depression-like behaviors of the perimenopausal 
depression modeling mice in TST and FST experiments, increased the memory of mice, and reduced the number of times of electric shock and immobility. Curculigoside also significantly increased the organ index of the thymus, spleen and uterus, increased the levels of E2 and T in serum, increased the concentration of 5-HT and DA in brain tissue, decreased the levels of FSH and LH in serum, and improved the histopathological damage of the uterus, hypothalamus, thymus and spleen [95].

\subsection{Male Reproductive Improvement}

Blamus $^{\mathrm{TM}}$, a standardized extract produced from C. orchioides, significantly enhanced the free testosterone in serum in male rats at a dose of $50 \mathrm{mg} / \mathrm{kg} \cdot \mathrm{bw}$. The structural integrities of seminiferous tubules, spermatogenesis, sperm morphology, interstitial cells and Sertoli cells in male rats were evidently improved after oral administration of Blamus ${ }^{\mathrm{TM}}$ at the doses of 10,25 or $50 \mathrm{mg} / \mathrm{kg} \cdot \mathrm{bw}[96,97]$.

\subsection{Cardio-Protection}

Zhao et al. (2020) reported that curculigoside (32) had a protective effect against myocardial ischemia-reperfusion injury (MIRI). In this study, curculigoside (32) significantly increased cell survival rate, and reduced mitochondrial-mediated cell apoptosis by inhibiting the opening of mitochondrial permeability transition pores (MPTP) [18].

\subsection{Other Activities}

Curculigoside A from the rhizome of $C$. orchioides improved the survival rate of random skin flaps in rats by inducing angiogenesis and alleviating ischemia-reperfusion $(\mathrm{I} / \mathrm{R})$ injury, increasing the VEGF and SOD expression and microvessel development and reducing the MDA level [98].

All of the pharmacological effects we mentioned in Part 3 were summarized in Table 1. 
Table 1. Pharmacological effects of the genus Curculigo.

\begin{tabular}{|c|c|c|c|c|c|c|c|c|}
\hline $\begin{array}{l}\text { Pharmacological } \\
\text { Activity }\end{array}$ & Tested Substance & Species & In Vivo/In Vitro & Model & $\begin{array}{c}\text { Administration } \\
\text { (In Vivo) }\end{array}$ & Dose/Concentration & Toxicology & References \\
\hline \multirow[t]{6}{*}{ Anti-diabetic Activity } & hydroalcoholic extract & C. orchioides & in vivo & $\begin{array}{l}\text { STZ-nicotinamide induced } \\
\text { diabetic nephropathy }\end{array}$ & oral administration & $600 \mathrm{mg} / \mathrm{kg}$ & - & [22] \\
\hline & ethanol extract & C. orchioides & in vivo & $\begin{array}{l}\text { STZ-nicotinamide induced } \\
\text { diabetic nephropathy }\end{array}$ & oral administration & $600 \mathrm{mg} / \mathrm{kg}$ & - & [22] \\
\hline & supplemented diet & C. pilosa & in vitro & STZ-induced diabetic rats & oral administration & $\begin{array}{l}5 \text { and } 10 \% \\
\text { CP-supplemented diet for } 21 \text { days }\end{array}$ & nephrotoxicity & {$[50]$} \\
\hline & corn steep liquor extract & C. pilosa & in vitro & STZ-induced diabetic rats & oral administration & $\begin{array}{l}300 \mathrm{mg} / \mathrm{kg} \text { of the extract(s) for } \\
28 \text { days }\end{array}$ & - & [51] \\
\hline & aqueous extract & C. latifolia & in vivo & $\begin{array}{l}\text { HFD+STZ-induced } \\
\text { diabetic rats }\end{array}$ & oral administration & $5 \mathrm{~g} / \mathrm{d}$ & non-toxic & [53] \\
\hline & ethanol extract & C. orchioides & in vitro & 3T3-L1 & - & 10 and $100 \mu \mathrm{g} / \mathrm{mL}$ & - & [54] \\
\hline \multirow[t]{10}{*}{ Anti-osteoporosis } & curculigoside & C. orchioides & in vitro & osteoblasts & - & $25-100 \mu \mathrm{g} / \mathrm{mL}$ & - & [16] \\
\hline & curculigoside & C. orchioides & in vitro & HAFSCs & - & $1-100 \mathrm{mg} / \mathrm{mL}$ & $\begin{array}{l}200 \mathrm{mg} / \mathrm{mL} \text { inhibit } \\
\text { cell growth }\end{array}$ & [23] \\
\hline & curculigoside & C. orchioides & in vitro & МС3Т3-E1 & - & $10 \mu \mathrm{M}$ & - & [24] \\
\hline & curculigoside & C. orchioides & in vivo & iron-overload mice model & oral administration & $100 \mathrm{mg} / \mathrm{kg}$ & - & {$[24]$} \\
\hline & COP70-3 & C. orchioides & in vitro & primary rat osteoblasts & - & - & non-toxic & [34] \\
\hline & curculigine E-H & C. orchioides & in vitro & MC3T3-E1 & - & $10 \mu \mathrm{M}$ & - & [44] \\
\hline & curculigine $\mathrm{M}, \mathrm{N}, \mathrm{O}$ & C. orchioides & in vitro & MC3T3-E1 & - & - & - & [45] \\
\hline & curculigine $\mathrm{K}, \mathrm{L}$ & C. orchioides & in vitro & МС3Т3-E1 & - & - & - & {$[46]$} \\
\hline & curculigoside & C. orchioides & in vivo & BMSCs & & $100 \mu \mathrm{M}$ & $\begin{array}{l}1000 \mu \mathrm{M} \text { decreased } \\
\text { cell viability }\end{array}$ & {$[60]$} \\
\hline & curculigoside & C. orchioides & in vivo & transgenic mice & oral administration & - & - & [61] \\
\hline \multirow[t]{3}{*}{ Antioxidant } & $\begin{array}{c}\text { corn steep liquor extract, } \\
\text { n-butanol and methanol } \\
\text { solvent fractions }\end{array}$ & C. pilosa & in vivo & STZ diabetic rats & oral administration & $300 \mathrm{mg} / \mathrm{kg}$ & - & [51] \\
\hline & ethanol extract & C. orchioides & in vitro & $\begin{array}{l}\text { cisplatin-induced HEI-OC1 } \\
\text { cell damage }\end{array}$ & - & $1-25 \mu \mathrm{g} / \mathrm{mL}$ & $\begin{array}{c}50 \mu \mathrm{g} / \mathrm{mL} \text { decreased } \\
\text { cell viability }\end{array}$ & [63] \\
\hline & methanol extract & C. orchioides & in vivo & $\begin{array}{c}\text { cyclophosphamide-induced } \\
\text { oxidative stress }\end{array}$ & oral administration & $25 \mathrm{mg} / \mathrm{kg}$ & non-toxic & {$[64]$} \\
\hline
\end{tabular}


Table 1. Cont.

\begin{tabular}{|c|c|c|c|c|c|c|c|c|}
\hline $\begin{array}{l}\text { Pharmacological } \\
\text { Activity }\end{array}$ & Tested Substance & Species & In Vivo/In Vitro & Model & $\begin{array}{l}\text { Administration } \\
\text { (In Vivo) }\end{array}$ & Dose/Concentration & Toxicology & References \\
\hline & $\begin{array}{l}\text { decoctions (DECs) and } \\
\text { hydro-alcoholic } \\
\text { extracts }\end{array}$ & C. orchioides & in vitro & $\begin{array}{l}\text { CCRF-CEM and } \\
\text { CEM/ADR5000 }\end{array}$ & - & $\begin{array}{l}43.57 \pm 4.21 \mathrm{mg} / \mathrm{mL} \text { and } \\
290.96 \pm 2.31 \mathrm{mg} / \mathrm{mL}\end{array}$ & non-toxic & [65] \\
\hline & hydro-alcoholic extract & C. orchioides & in vitro & - & oral administration & $100 \mathrm{mg} / \mathrm{kg}$ & - & [66] \\
\hline & $\begin{array}{l}\text { ethylacetate fraction, } \\
\text { aqueous ethylacetate }\end{array}$ & C. orchioides & in vivo & - & oral administration & $52 \pm 0.66 \mu \mathrm{g} / \mathrm{mL}$ & - & [67] \\
\hline & aqueous extract & C. pilosa & in vitro & rat penile homogenate & - & $0.95 \mathrm{mg} / \mathrm{mL}$ & & [68] \\
\hline & Curculigo pilosa & C. pilosa & in vivo & received the high-fat diet & oral administration & $0.3 \mathrm{~mL} / \mathrm{kg}$ & - & [69] \\
\hline \multirow[t]{9}{*}{ Neuroprotective effect } & orcinol glucoside & C. orchioides & in vivo & $\begin{array}{l}\text { CUMS-induced depressive } \\
\text { rats }\end{array}$ & - & $1.5,3,6 \mathrm{mg} / \mathrm{kg}$ & - & [19] \\
\hline & crassifoside $\mathrm{H}$ & C. orchioides & in vivo & $\begin{array}{l}\text { CUMS-induced depressive } \\
\text { rats }\end{array}$ & oral administration & 2,4, or $8 \mathrm{mg} / \mathrm{kg}$ & - & [21] \\
\hline & curculigoside & C. orchioides & in vivo & SD rats & oral administration & $24,48,72 \mathrm{mg} / \mathrm{kg}$, qd & - & [74] \\
\hline & methanol extract & C. orchioides & in vivo & $\begin{array}{l}\text { Cyclophosphamide-Induced } \\
\text { Neurotoxicity in Murine } \\
\text { Model }\end{array}$ & i.p. & $200 \mathrm{mg} / \mathrm{kg}, 400 \mathrm{mg} / \mathrm{kg}$ & - & [75] \\
\hline & curculigoside & C. orchioides & in vivo & mice & oral administration & $10,20,40 \mathrm{mg} / \mathrm{kg}$ & - & [76] \\
\hline & curculigoside A & C. orchioides & in vitro & $\begin{array}{l}\text { human brain microvascular } \\
\text { endothelial cell line }\end{array}$ & - & $1-24 \mu \mathrm{M}$ & - & [78] \\
\hline & curculigoside A & C. orchioides & in vivo & $\begin{array}{c}\text { middle cerebral artery } \\
\text { occluded (MCAO) model rats }\end{array}$ & tail vein injection & $10 \mathrm{mg} / \mathrm{kg}$ & - & [79] \\
\hline & curculigoside & C. orchioides & in vitro & $\begin{array}{l}\text { N-methyl-D-aspartate } \\
\text { (NMDA)-induced } \\
\text { neuronal cell }\end{array}$ & - & 1 and $10 \mu \mathrm{M}$ & - & [80] \\
\hline & crassifoside $\mathrm{H}$ & C.glabrescens & in vivo & $\begin{array}{l}\text { chronic unpredictable mild } \\
\text { stress (CUMS)-induced rats }\end{array}$ & oral administration & 2,4 , and $8 \mathrm{mg} / \mathrm{kg} \mathrm{d}^{-1}$ & - & [81] \\
\hline \multirow[t]{4}{*}{ Antitumor } & polysaccharides & C. orchioides & in vivo & mice injected with Hela cells & $\begin{array}{l}\text { injected into the lower } \\
\text { abdominal region }\end{array}$ & $20,40 \mathrm{mg} / \mathrm{kg}$ & - & [27] \\
\hline & polysaccharides & C. orchioides & in vitro & Hela cells & - & $10,20,40,80 \mathrm{mg} / \mathrm{mL}$ & - & [27] \\
\hline & CoBAgNPs & C. orchioides & in vitro & $\begin{array}{c}\text { human breast } \\
\text { cancer cells and Vero cells }\end{array}$ & - & $18.86,42.43 \mu \mathrm{g} / \mathrm{mL}$ & - & [82] \\
\hline & the ethyl acetate extract & C. orchioides & in vitro & MCRF-7 cells & - & $80 \mu \mathrm{g} / \mathrm{mL}$ & - & [83] \\
\hline
\end{tabular}


Table 1. Cont.

\begin{tabular}{|c|c|c|c|c|c|c|c|c|}
\hline $\begin{array}{c}\text { Pharmacological } \\
\text { Activity }\end{array}$ & Tested Substance & Species & In Vivo/In Vitro & Model & $\begin{array}{c}\text { Administration } \\
\text { (In Vivo) }\end{array}$ & Dose/Concentration & Toxicology & References \\
\hline & curculigoside & C. orchioides & in vivo & C57BL/6 mice & - & $5 \mathrm{mg} / \mathrm{kg}$ & non-toxic & [84] \\
\hline & $\begin{array}{l}\text { orcinolglucoside nano- } \\
\text { lipid carrier (NLC) }\end{array}$ & C. orchioides & in vitro & $\begin{array}{l}\text { gastrointestinal tract } \\
\text { (GIT), colon and hepatoma } \\
\text { carcinoma cell lines }\end{array}$ & - & - & - & [85] \\
\hline \multirow[t]{5}{*}{ Antibacteria } & the ethanol extract & C. orchioides & in vitro & S. pyogenes & - & $49 \mu \mathrm{g} / \mathrm{mL}$ & - & [87] \\
\hline & Coble-AgNPs & C. orchioides & in vitro & $\begin{array}{l}\text { Pseudomonas aeruginosa and } \\
\text { Staphylococcus aureus }\end{array}$ & - & $50 \mu \mathrm{L}$ & $\begin{array}{l}6.33 \mu \mathrm{g} / \mathrm{mL} \text { inhibit } \\
\text { cell growth }\end{array}$ & [88] \\
\hline & $\begin{array}{l}\text { the constituents of } \\
\text { ethanol crude extract } \\
\text { and the neutral } \\
\text { metabolite }\end{array}$ & C. pilosa & in vitro & $\begin{array}{l}\text { Escherichia coli, Staphylococcus } \\
\text { aureus, Pseudomonas aeruginosa } \\
\text { and Streptococcus faecalis }\end{array}$ & - & $100 \mathrm{mg} / \mathrm{mL}$ & - & [89] \\
\hline & methanol extract & C. recurvata & in vitro & $\begin{array}{l}\text { Bacillus cereus, Salmonella } \\
\text { typhi, Escherichia coli, }\end{array}$ & - & - & $\begin{array}{l}\text { LD50 was found to be } \\
\text { greater than } \\
4000 \mathrm{mg} / \mathrm{kg}\end{array}$ & {$[90]$} \\
\hline & $\begin{array}{c}\text { a newly isolated } \\
\text { streptomyces sp. 5-10 }\end{array}$ & C.capitulata & in vitro & FocTR4 & - & $250 \mu \mathrm{g} / \mathrm{mL}, 500 \mu \mathrm{g} / \mathrm{mL}$ & - & [91] \\
\hline \multirow[t]{2}{*}{$\begin{array}{l}\text { Anti-inflammation and } \\
\text { Anti-arthritis }\end{array}$} & curculigoside & C. orchioides & in vivo & $\begin{array}{l}\text { type II collagen induced rat } \\
\text { arthritis model }\end{array}$ & oral administration & $50 \mathrm{mg} / \mathrm{kg}$ & - & {$[26]$} \\
\hline & curculigoside & C. orchioides & in vitro & MH7A cells & - & 4,8 and $16 \mu \mathrm{g} / \mathrm{mL}$ & - & {$[26]$} \\
\hline $\begin{array}{l}\text { Anti-diarrhea and } \\
\text { anti-nociception }\end{array}$ & methanol extract & C. recurvata & in vivo & mice & oral administration & $200,400 \mathrm{mg} / \mathrm{kg}$ & lower toxicity & [93] \\
\hline \multirow[t]{2}{*}{$\begin{array}{c}\text { Effect on } \\
\text { perimenopausal } \\
\text { syndrome }\end{array}$} & total glucosides & C. orchioides & in vivo & the castrated mice & oral administration & $400 \mathrm{mg} / \mathrm{kg}$ & - & [94] \\
\hline & total glucosides & C. orchioides & in vivo & Perimenopausal mdel mice & oral administration & $400,200,100 \mathrm{mg} / \mathrm{kg}$ & - & [95] \\
\hline $\begin{array}{l}\text { Male reproductive } \\
\text { improvement }\end{array}$ & Blamus $^{\mathrm{TM}}$ & C. orchioides & in vitro & - & - & - & & {$[96,97]$} \\
\hline \multirow[t]{2}{*}{ Cardio-protection } & curculigoside & C. orchioides & in vitro & H9c2 cells & - & $10,15 \mu \mathrm{M}$ & - & {$[18]$} \\
\hline & curculigoside & C. orchioides & in vivo & rat & intravenous injection & $10,15 \mathrm{mg} / \mathrm{kg}$ & - & \\
\hline Other activities & curculigoside A & C. orchioides & in vivo & Sprague-Dawley rats & oral administration & 10 or $20 \mathrm{mg} / \mathrm{kg}$ & - & [98] \\
\hline
\end{tabular}




\section{Conclusions}

Most Curculigo species are used as folk or ethno-medicines in the regions of Asia and Africa. Among them, C. orchioides is a traditional medicinal herb with a long use history in Asian countries such as China, India, Nepal and Malaysia, etc. Curculigo plants have been reported to have diverse bioactive constituents including polysaccharides, norlignans, phenolics, and terpenoids. In this work, we provided an updated review on the phytochemistry and pharmacological activities of the medicinal plants of the genus Curculigo, from 2013 up to now. A total of 61 compounds have been isolated from the medicinal herbs of Curculigo, and it was revealed that phenolics were the main bioactive constituents in the plants of Curculigo. Recent modern pharmacological studies have demonstrated a variety of activities of the plants of Curculigo in vivo and in vitro, including anti-diabetes, anti-osteoporosis, anti-oxidation and lipid peroxidation inhibition, antidepression, anti-arthritis, anti-nociception, anti-tumor, anti-bacteria, inhibition of ischemiareperfusion injury, alleviation of perimenopausal syndrome and enhancement of male reproduction. It should be pointed out that $C$. orchioides is the species of most concerned in the genus Curculigo, and curculigoside and orcinol glucoside were the two main compounds in it.

Overall, herein, the updated advance on the medicinal plants of genus Curculigo, including the isolation, structural characterization, pharmacological activities, and relevant molecular mechanisms of the active compounds or extracts from medicinal plants of genus Curculigo, were summarized from 2013 up to now. The aim of this present review is to provide valuable references for researchers, and to promote the reasonable and scientific development and utilization of the medicinal resource of the genus Curculigo.

Author Contributions: Y.W., contributed to literature search and writing the manuscript. J.L., contributed to the table and figures. N.L., contributed to the conception and design of the review. All authors have read and agreed to the published version of the manuscript.

Funding: This study was supported by the National Natural Science Foundation of China (31670353) and key research and development projects in Anhui Province (202004a07020035).

Institutional Review Board Statement: Not applicable.

Informed Consent Statement: Not applicable.

Data Availability Statement: Data sharing not applicable to this article as no datasets were generated or analysed during the current study. Our manuscript does not produce new data; all available data are contained in the non published material.

Conflicts of Interest: The authors declare no conflict of interest.

\section{References}

1. Li, L.Y.; Chen, D.X.; Qin, S.Y.; Li, Q.S.; Zhong, G.Y. Studies on genetic relationship of seven species of Curculigo plant from China using SRAP. China J. Chin. Mater. Med. 2008, 33, 117-120.

2. World Checklist of Hypoxidaceae. Facilitated by the Royal Botanic Gardens, Kew. Available online: http://apps.kew.org/wcsp/ (accessed on 20 March 2016).

3. Chinese Academy of Sciences; Editorial Board of Flora of China. Flora of China; Science Press: Beijing, China, 2000; Volume 24, pp. 264-273.

4. Mehta, J.; Nama, K.S. A Review on Ethnomedicines of Curculigo orchioides Gaertn (Kali Musli): Black Gold. Int. J. Pharm. Biomedic. Res. 2014, 1, 12-16.

5. Editorial Board of China Herbal. China Herbal (Chinese Herbal Medicine); Shanghai Science and Technology Press: Shanghai, China, 1999; Volume 22, pp. 215-219.

6. Khare, C.P. Indian Medicinal Plants; Springer: Berlin/Heidelberg, Germany, 2007; p. 22.

7. Editorial Board of China Herbal. China Herbal (Chinese Herbal Medicine); Shanghai Science and Technology Press: Shanghai, China, 2005; Volume 34, pp. 104-105.

8. Chen, X.Q. The Genus Curculigo in China. Acta Phytotaxon. Sin. 1966, 11, 131-132.

9. Karigidi, K.O.; Olaiya, C.O. In vitro Antidiabetic, Antioxidant and Antilipid peroxidative Activities of Corn Steep Liquor Extracts of Curculigo pilosa and its Solvent Fractions. J. Herbs Spices Med. Plants 2019, 25, 377-388. [CrossRef] 
10. Kusamba, C.; Messana, I.; Galeffi, C.; De Vicente, Y. Research on African medicinal plants -XXV- the $(1,2 S)$ absolute configuration of nyasicoside. Its occurrence in Curculigo recurvata. Tetrahedron 1991, 47, 4369-4374.

11. Nie, Y.; Dong, X.; He, Y.J.; Yuan, T.T.; Han, T.; Rahman, K.; Qin, L.P.; Zhang, Q.Y. Medicinal plants of genus Curculigo: Traditional uses and a phytochemical and ethnopharmacological review. J. Ethnopharmacol. 2013, 147, 547-563. [CrossRef] [PubMed]

12. Chen, Q.S.; Chen, W.Q.; Yang, S.Y. Pharmacologic study of Curculigo orchioides Gaertn. China J. Chin. Mater. Med. 1989, 14, 618-620.

13. Lakshmi, V.; Pandey, K.; Puri, A.; Saxena, R.; Saxena, K. Immunostimulant principles from Curculigo orchioides. J. Ethnopharmacol. 2003, 89, 181-184. [CrossRef]

14. Wang, K.-J.; Li, N. Antioxidant phenolic compounds from rhizomes of Curculigo crassifolia. Arch. Pharm. Res. 2007, 30, 8-12. [CrossRef] [PubMed]

15. Wang, K.-J.; Li, N. Norlignan derivatives from Curculigo crassifolia and their DPPH radical scavenging activity. Arch. Pharm. Res. 2008, 31, 1313-1316. [CrossRef]

16. Zhu, F.B.; Wang, J.Y.; Zhang, Y.L.; Quan, R.F.; Yue, Z.S.; Zeng, L.R.; Zheng, W.J.; Hou, Q.; Yan, S.G.; Hu, Y.G. Curculigoside regulates proliferation, differentiation, and pro-inflammatory cytokines levels in dexamethasone -induced rat calvarial osteoblasts. Int. J. Clin. Exp. Med. 2015, 8, 12337-12346. [PubMed]

17. Chauhan, N.; Rao, C.V.; Dixit, V. Effect of Curculigo orchioides rhizomes on sexual behaviour of male rats. Fitoterapia 2007, 78, 530-534. [CrossRef]

18. Zhao, Y.; Guo, Y.; Chen, Y.; Liu, S.; Wu, N.; Jia, D. Curculigoside attenuates myocardial ischemia-reperfusion injury by inhibiting the opening of the mitochondrial permeability transition pore. Int. J. Mol. Med. 2020, 45, 1514-1524. [CrossRef]

19. Ge, J.-F.; Gao, W.-C.; Cheng, W.-M.; Lu, W.-L.; Tang, J.; Peng, L.; Li, N.; Chen, F.-H. Orcinol glucoside produces antidepressant effects by blocking the behavioural and neuronal deficits caused by chronic stress. Eur. Neuropsychopharmacol. 2014, 24, 172-180. [CrossRef]

20. Miao, M.; Tian, S.; Bai, M.; Weiyun, X. Total glucosides of Curculigo rhizome to perimenopausal period mice model. Pak. J. Pharm. Sci. 2017, 30, 975-978.

21. Zhang, Y.; Ge, J.-F.; Wang, F.-F.; Liu, F.; Shi, C.; Li, N. Crassifoside H improve the depressive-like behavior of rats under chronic unpredictable mild stress: Possible involved mechanisms. Brain Res. Bull. 2017, 135, 77-84. [CrossRef] [PubMed]

22. Singla, K.; Singh, R. Nephroprotective effect of Curculigo orchiodies in streptozotocin-nicotinamide induced diabetic nephropathy in wistar rats. J. Ayurveda Integr. Med. 2020, 11, 399-404. [CrossRef] [PubMed]

23. Liu, M.; Li, Y.; Yang, S.-T. Curculigoside Improves Osteogenesis of Human Amniotic Fluid-Derived Stem Cells. Stem Cells Dev. 2014, 23, 146-154. [CrossRef] [PubMed]

24. Zhang, Q.L.; Zhao, L.; Shen, Y.; He, Y.Q.; Cheng, G.; Yin, M.; Zhang, Q.Y.; Qin, L.P. Curculigoside Protects against ex-cess-ironinduced bone loss by attenuating Akt-FoxO1- dependent oxidative damage to mice and osteoblastic MC3T3-E1 cells. Oxid. Med. Cell. Longev. 2019, 2019, 1-14. [CrossRef]

25. Zhang, J.; Li, Y.D.; Liu, X.M.; Gao, L.; Zhang, Y.P.; Dang, L.Z. The study of terpeniods from Curculigo orchioides. J. Yunnan Univ. 2019, 41,367-371.

26. Tan, S.; Xu, J.; Lai, A.; Cui, R.; Bai, R.; Liang, W.; Zhang, G.; Jiang, S.; Liu, S.; Zheng, M.; et al. Curculigoside exerts sig-nificant anti-arthritic effects in vivo and in vitro via regulation of the JAK/STAT/NF-кB signaling pathway. Mol. Med. Rep. 2019, 19, 2057-2064.

27. Xia, L.-F.; Liang, S.-H.; Tang, J.; Huang, Y.; Wen, H. Anti-tumor effect of polysaccharides from rhizome of Curculigo orchioides Gaertn on cervical cancer. Trop. J. Pharm. Res. 2016, 15, 1731. [CrossRef]

28. Venkatesh, P.; Mukherjee, P.K.; Kumar, S.N.; Nema, N.K.; Bandyopadhyay, A.; Fukui, H.; Mizuguchi, H. Mast cell stabilization and antihistaminic potentials of Curculigo orchioides rhizomes. J. Ethnopharmacol. 2009, 126, 434-436. [CrossRef]

29. Zabidi, N.A.; Ishak, N.A.; Hamid, M.; Ashari, S.E.; Latif, M.A.M. Inhibitory evaluation of Curculigo latifolia on $\alpha$-glucosidase, DPP (IV) and in vitro studies in antidiabetic with molecular docking relevance to type 2 diabetes mellitus. J. Enzym. Inhib. Med. Chem. 2021, 36, 109-121. [CrossRef] [PubMed]

30. Chen, Z.Q.; Liu, X.X.; Yi, X.H.; Zhou, J.; Yang, D. Research progress on chemical constituents of genus Curculigo. J. Guilin Norm. Coll. 2012, 26, 163-169. (In Chinese)

31. Yang, H.; Pei, G.; Chen, S.B. Research progress on medicinal herbs of genus Curculigo. Cent. South Pharm. 2011, 9, 916-920. (In Chinese)

32. Pradeep, G.; Atul, K. A review on phytochemical and pharmacological profile on Curculigo orchioides. Plant Cell Bio-Technol. Mol. Biol. 2020, 21, 243-252.

33. Wang, X.; Zhang, M.; Zhang, D.; Wang, S.; Yan, C. An O-acetyl-glucomannan from the rhizomes of Curculigo orchioides: Structural characterization and anti-osteoporosis activity in vitro. Carbohydr. Polym. 2017, 174, 48-56. [CrossRef]

34. Wang, X.; Zhang, M.; Zhang, D.; Wang, S.M.; Yan, C.Y. Structural elucidation and anti-osteoporosis activities of polysaccha-rides obtained from Curculigo orchioides. Carbohydr. Polym. 2019, 203, 292-301. [CrossRef]

35. Niu, C.; Zhang, Z.Z.; Yang, L.P.; Zhai, Y.Y.; Wang, Z.H. Chemical Constituents of Curculigo orchioides. Chem. Nat. Compd. 2020, 56, 1-3. [CrossRef]

36. Li, N.; Chen, J.-J.; Zhao, Y.-X.; Zhou, J. Three new norlignans from Curculigo capitulata. J. Asian Nat. Prod. Res. 2005, 7, 189-195. [CrossRef] 
37. Li, N.; Wang, K.-J.; Chen, J.-J.; Zhou, J. Two novel glucosyl-fused compounds from Curculigo crassifolia (Hypoxidaceae). Tetrahedron Lett. 2005, 46, 6445-6447. [CrossRef]

38. Li, N.; Li, S.-P.; Wang, K.-J.; Yan, G.-Q.; Zhu, Y.-Y. Novel norlignan glucosides from rhizomes of Curculigo sinensis. Carbohydr. Res. 2012, 351, 64-67. [CrossRef]

39. Li, S.; Yu, J.-H.; Fan, Y.-Y.; Liu, Q.-F.; Li, Z.-C.; Xie, Z.-X.; Li, Y.; Yue, J.-M. Structural Elucidation and Total Synthesis of Three 9-Norlignans from Curculigo capitulata. J. Org. Chem. 2019, 84, 5195-5202. [CrossRef]

40. Paresh, M.V.; Chepuri, V.R. Total synthesis of sinenside A. Org. Lett. 2015, 17, 1717-1724.

41. Xu, J.P.; Dong, Q.Y. Chemical study on Curculigo orchioides II, The isolation and structural determination of new compound curculigine A. Chin. Tradit. Herb. Drugs 1987, 18, 194-196. (In Chinese)

42. Xu, J.P.; Xu, R.S. Phenyl glucosides Curculigo orchioides. Acta Pharm. Sin. 1992, 27, 353-357.

43. Cao, D.P.; Han, T.; Zheng, Y.N.; Qin, L.P.; Zhang, Q.Y. Phenolic glycosides and lignans components in Curculigo orchioides Gaertn. Acad. J. Second Milit. Univ. 2009, 30, 194-197. [CrossRef]

44. Wang, Z.-H.; Huang, J.; Ma, X.-C.; Li, G.-Y.; Ma, Y.-P.; Li, N.; Wang, J.-H. Phenolic glycosides from Curculigo orchioides Gaertn. Fitoterapia 2013, 86, 64-69. [CrossRef] [PubMed]

45. Wang, Z.H.; Ma, X.C.; Li, G.Y.; Niu, C.; Ma, Y.P.; Kasimu, R.; Huang, J.; Wang, J.H. Four new phenolic glucosides from Curculigo orchioides Gaertn. Phytochem. Lett. 2014, 9, 153-157. [CrossRef]

46. Wang, Z.H.; Gong, X.Y.; Zhou, D.J.; Xu, P.F.; Huang, M.; Zhang, Q.L.; Meng, Y.L.; Niu, C.; Zhang, Y.R. Three new chloro-phenolic glucosides from Curculigo orchioides Gaertn. Phytochem. Lett. 2018, 26, 9-11. [CrossRef]

47. Deng, X.-L.; Zheng, R.-R.; Han, Z.-Z.; Gu, L.-H.; Wang, Z.-T. New chlorophenolic glycoside from Curculigo orchioides and their activities on $5 \alpha$-reductase. J. Asian Nat. Prod. Res. 2020, 22, 1-8. [CrossRef]

48. Chen, X.; Zuo, A.; Deng, Z.; Huang, X.; Zhang, X.; Geng, C.; Li, T.; Chen, J. New phenolic glycosides from Curculigo orchioides and their xanthine oxidase inhibitory activities. Fitoterapia 2017, 122, 144-149. [CrossRef] [PubMed]

49. Jiao, W.; Chen, X.; Wang, H.; Lu, R.; Shao, H. A new hepatotoxic triterpenoid ketone from Curculigo orchioides. Fitoterapia 2013, 84, 1-5. [CrossRef]

50. Karigidi, K.O.; Akintimehin, E.S.; Omoboyowa, D.A.; Adetuyi, F.O.; Olaiya, C.O. Effect of Curculigo pilosa supplemented diet on blood sugar, lipid metabolism, hepatic oxidative stress and carbohydrate metabolism enzymes in streptozotocin-induced diabetic rats. J. Diabetes Metab. Disord. 2020, 19, 1173-1184. [CrossRef]

51. Karigidi, K.O.; Olaiya, C.O. Curculigo pilosa mitigates against oxidative stress and structural derangements in pancreas and kidney of streptozotocin-induced diabetic rats. J. Complement. Integr. Med. 2020, 20190217. [CrossRef]

52. Karigidi, K.O.; Olaiya, C.O. Antidiabetic activity of corn steep liquor extract of Curculigo pilosa and its solvent fractions in streptozotocin-induced diabetic rats. J. Tradit. Complement. Med. 2020, 10, 555-564. [CrossRef] [PubMed]

53. Ishak, N.A.; Ismail, M.; Hamid, M.; Ahmad, Z.; Ghafar, S.A.A. Antidiabetic and Hypolipidemic Activities of Curculigo latifolia Fruit:Root Extract in High Fat Fed Diet and Low Dose STZ Induced Diabetic Rats. Evid. Based Complement. Altern. Med. 2013, 2013, 601838. [CrossRef] [PubMed]

54. Gulati, V.; Gulati, P.; Harding, I.H.; Palombo, E.A. Exploring the anti-diabetic potential of Australian Aboriginal and Indian Ayurvedic plant extracts using cell-based assays. BMC Complement. Altern. Med. 2015, 15, 8. [CrossRef]

55. Rodan, G.A.; Martin, T.J. Therapeutic approaches to bone diseases. Science 2000, 289, 1508-1514. [CrossRef]

56. Cao, D.; Zheng, Y.; Qin, L.; Han, T.; Zhang, H.; Rahman, K.; Zhang, Q. Curculigo orchioides, a traditional Chinese medicinal plant, prevents bone loss in ovariectomized rats. Maturitas 2008, 59, 373-380. [CrossRef]

57. Han, J.; Wan, M.; Ma, Z.; Hu, C.; Yi, H. Prediction of Targets of Curculigoside A in Osteoporosis and Rheumatoid Arthritis Using Network Pharmacology and Experimental Verification. Drug Des. Dev. Ther. 2020, 14, 5235-5250. [CrossRef] [PubMed]

58. Zhao, G.; Yuan, F.; Zhu, J. An LC-MS/MS method for determination of curculigoside with anti-osteoporotic activity in rat plasma and application to a pharmacokinetic study. Biomed. Chromatogr. 2013, 28, 341-347. [CrossRef]

59. Wang, N.; Zhao, G.; Zhang, Y.; Wang, X.; Zhao, L.; Xu, P.; Shou, D. A Network Pharmacology Approach to Determine the Active Components and Potential Targets of Curculigo orchioides in the Treatment of Osteoporosis. Med. Sci. Monit. 2017, 23, 5113-5122. [CrossRef] [PubMed]

60. Shen, Q.P.; Zeng, D.L.; Zhou, Y.T.; Xia, L.G.; Zhao, Y.F.; Qiao, G.Y.; Xu, L.Y.; Liu, Y.; Zhu, Z.Y.; Jiang, X.Q. Curculigoside promotes osteogenic differentiation of bone marrow stromal cells from ovariectomized rats. J. Pharm. Pharmacol. 2013, 65, 1005-1013. [CrossRef]

61. Zhao, L.; Liu, S.; Wang, Y.; Zhang, Q.; Zhao, W.; Wang, Z.; Yin, M. Effects of Curculigoside on Memory Impairment and Bone Loss via Anti-Oxidative Character in APP/PS1 Mutated Transgenic Mice. PLoS ONE 2015, 10, e0133289. [CrossRef] [PubMed]

62. Halliwell, B. Free radicals, antioxidants, and human disease: Curiosity, cause, or consequence? Lancet 1994, 344, 721-724. [CrossRef]

63. Kang, T.H.; Na Hong, B.; Jung, S.-Y.; Lee, J.-H.; So, H.-S.; Park, R.; You, Y.-O. Curculigo orchioides Protects Cisplatin-Induced Cell Damage. Am. J. Chin. Med. 2013, 41, 425-441. [CrossRef] [PubMed]

64. Murali, V.P.; Kuttan, G. Enhancement of Cancer Chemotherapeutic Efficacy of Cyclophosphamide by Curculigo orchioides Gaertn and Its Ameliorative Effects on Cyclophosphamide-Induced Oxidative Stress. Integr. Cancer Ther. 2015, 14, 172-183. [CrossRef] 
65. Tacchini, M.; Spagnoletti, A.; Marieschi, M.; Caligiani, A.; Bruni, R.; Efferth, T.; Sacchetti, G.; Guerrini, A. Phytochemical profile and bioactivity of traditional ayurvedic decoctions and hydro-alcoholic macerations of Boerhaavia diffusa L. and Curculigo orchioides Gaertn. Nat. Prod. Res. 2015, 29, 2071-2079. [CrossRef] [PubMed]

66. Navya, K.; Kumar, G.; Anilakumar, K. Ameliorating effect of Curculigo orchoides on chromium(VI) induced oxidative stress via, modulation of cytokines, transcription factors and apoptotic genes. J. Appl. Biomed. 2017, 15, 299-306. [CrossRef]

67. Hejazi, I.I.; Khanam, R.; Mehdi, S.H.; Bhat, A.R.; Rizvi, M.M.A.; Thakur, S.C.; Athar, F. Antioxidative and anti-proliferative potential of Curculigo orchioides Gaertn in oxidative stress induced cytotoxicity: In vitro, exvivo and in silico studies. Food Chem. Toxicol. 2018, 115, 244-259. [CrossRef] [PubMed]

68. Adefegha, S.A.; Oyeleye, S.I.; Oboh, G. African crocus (Curculigo pilosa) and wonderful kola (Buchholzia coriacea) seeds modulate critical enzymes relevant to erectile dysfunction and oxidative stress. J. Complement. Integr. Med. 2018, 15. [CrossRef] [PubMed]

69. Ogunlana, O.O.; Ogunlana, O.E.; Ugochukwu, S.K.; Adeyemi, A.O. Assessment of the ameliorative effect of Ruzu Herbal Bitters on the biochemical and antioxidant abnormalities induced by high fat diet in Wistar rats. Int. J. Pharmacol. 2018, 14, 329-341. [CrossRef]

70. Farzinebrahimi, R.; Taha, R.M.; Rashid, K.A.; Ahmed, B.A.; Danaee, M.; Rozali, S.E. Preliminary Screening of Antioxidant and Antibacterial Activities and Establishment of an Efficient Callus Induction in Curculigo latifolia Dryand (Lemba). Evid. Based Complement. Altern. Med. 2016, 2016, 1-9. [CrossRef]

71. Zabidi, N.A.; Ishak, N.A.; Hamid, M.; Ashari, S.E. Subcritical Water Extraction of Antioxidants from Curculigo latifolia Root. J. Chem. 2019, 2019, 1-10. [CrossRef]

72. Pratap, G.K.; Shantaram, M. A kinetic study of acetylcholinesterase inhibition by fractions of Oleo dioica Roxb. leaf and Curculigo orchioides Gaertn rhizome for the treatment of Alzheimer's disease. EJMP 2019, 30, 1-12.

73. Pratap, G.K. In Vitro Anti-Cholinesterase activity and mass spectrometric analysis of Curculigo orchioides Gaertn. Rhizome ex-tract. Anal. Chem. Lett. 2020, 10, 442-458. [CrossRef]

74. Li, R.C.; Zeng, M.Y.; Su, Y.L.; Wu, C.X. Effects of curculigoside on the behavior and hippocampal neuronal apoptosis of Alzheimer's rat. Chin. J. Clin. Pharmacol. 2019, 35, 654-670. (In Chinese)

75. Ramchandani, D.; Ganeshpurkar, A.; Bansal, D.; Karchuli, M.S.; Dubey, N. Protective Effect of Curculigo orchioides Extract on Cyclophospha-mide-Induced Neurotoxicity in Murine Model. Toxicol. Int. 2014, 21, 232-235.

76. Wang, J.; Zhao, X.-L.; Gao, L. Anti-depressant-like effect of curculigoside isolated from Curculigo orchioides Gaertn root. Trop. J. Pharm. Res. 2016, 15, 2165. [CrossRef]

77. Yang, S.-J.; Song, Z.-J.; Wang, X.-C.; Zhang, Z.-R.; Wu, S.-B.; Zhu, G.-Q. Curculigoside facilitates fear extinction and prevents depression-like behaviors in a mouse learned helplessness model through increasing hippocampal BDNF. Acta Pharmacol. Sin. 2019, 40, 1269-1278. [CrossRef] [PubMed]

78. Kang, Z.; Zhu, H.; Luan, H.; Han, F.; Jiang, W. Curculigoside A induces angiogenesis through VCAM-1/Egr-3/CREB/VEGF signaling pathway. Neuroscience 2014, 267, 232-240. [CrossRef] [PubMed]

79. Zhu, H.; He, J.; Ye, L.; Lin, F.; Hou, J.; Zhong, Y.; Jiang, W. Mechanisms of angiogenesis in a Curculigoside A-treated rat model of cerebral ischemia and reperfusion injury. Toxicol. Appl. Pharmacol. 2015, 288, 313-321. [CrossRef] [PubMed]

80. Tian, Z.; Yu, W.; Liu, H.-B.; Zhang, N.; Li, X.-B.; Zhao, M.-G.; Liu, S.-B. Neuroprotective effects of curculigoside against NMDA-induced neuronal excitoxicity in vitro. Food Chem. Toxicol. 2012, 50, 4010-4015. [CrossRef]

81. Li, H.N.; Wu, K.F.; Zhang, Y.; Li, N.; Wang, K.J. Crassifoside H ameliorates depressant-like behavior in CUMS rats: Involving improvement of HPA axis dysfunction and inhibition of inflammation in hippocampus. Trop. J. Pharm. Res. 2020, 19, 1693-1699. [CrossRef]

82. Kayalvizhi, T.; Ravikumar, S.; Venkatachalam, P. Green Synthesis of Metallic Silver Nanoparticles Using Curculigo orchioides Rhizome Extracts and Evaluation of Its Antibacterial, Larvicidal, and Anticancer Activity. J. Environ. Eng. 2016, 142, 4016002. [CrossRef]

83. Selvaraj, T.; Agastian, P. In vitro anticancer activity of ethyl acetate extract and green nanoparticles synthesized from Curculigo orchioides gaertn-An endangered medicinal. Int. J. Pharm. Sci. Res. 2017, 8, 3030-3038.

84. Murali, V.P.; Kuttan, G. Curculigoside augments cell-mediated immune responses in metastatic tumor-bearing animals. Immunopharmacol. Immunotoxicol. 2016, 38, 264-269. [CrossRef]

85. Nahak, P.; Gajbhiye, R.L.; Karmakar, G.; Guha, P.; Roy, B.; Besra, S.E.; Bikov, A.G.; Akentiev, A.V.; Noskov, B.A.; Nag, K.; et al. Orcinol Glucoside Loaded Polymer-Lipid Hybrid Nanostructured Lipid Carriers: Potential Cytotoxic Agents against Gastric, Colon and Hepatoma Carcinoma Cell Lines. Pharm. Res. 2018, 35, 198. [CrossRef]

86. Wang, X.; Xu, L.; Lao, Y.; Zhang, H.; Xu, H. Natural Products Targeting EGFR Signaling Pathways as Potential Anti-cancer Drugs. Curr. Protein Pept. Sci. 2018, 19, 380-388. [CrossRef]

87. Marasini, B.P.; Baral, P.; Aryal, P.; Ghimire, K.R.; Sanjiv, N.; Nabaraj, D.; Anjana, S.; Laxman, G.; Kanti, S. Evaluation of antibacterial activity of some traditionally used medicinal plants against human pathogenic bacteria. BioMed Res. Int. 2015, $2015,265425$. [CrossRef]

88. Perumal, V.; Thamilchelvan, K.; Jinu, U.; Giovanni, B.; Natesan, G. Enhanced antibacterial and cytotoxic activity of phyto-chemical loaded-silver nanoparticles using Curculigo orchioides leaf extracts with different extraction techniques. J. Cluster Sci. 2017, 28, 607-619. 
89. Nwokonkwo, D.C. Antibacterial Susceptibility of the Constituents of Ethanol Crude Extract and the Neutral Metabolite of the Root of Curculigo pilosa Hypoxidaceae. Int. J. Chem. 2014, 6, 19-23. [CrossRef]

90. Kabir, M.; Ahmad, S.; Mahamoud, M.S.; Chakrabarty, N.; Shoibe, M. Comparative study of hypoglycemic and antibacterial activity of organic extracts of four Bangladeshi plants. J. Coast. Life Med. 2016, 4, 231-235. [CrossRef]

91. Yun, T.; Zhang, M.; Zhou, D.; Jing, T.; Zang, X.; Qi, D.; Chen, Y.; Li, K.; Zhao, Y.; Tang, W.; et al. Anti-Foc RT4 Activity of a Newly Isolated Streptomyces sp. 5-10 From a Medicinal Plant (Curculigo capitulata). Front. Microbiol. 2021, 11, 98. [CrossRef] [PubMed]

92. Ding, H.; Gao, G.; Zhang, L.; Shen, G.; Sun, W.; Gu, Z.; Fan, W. The protective effects of curculigoside A on adjuvant-induced arthritis by inhibiting NF-кB/NLRP3 activation in rats. Int. Immunopharmacol. 2016, 30, 43-49. [CrossRef] [PubMed]

93. Ahmad, S.; Nasrin, M.S.; Reza, A.S.M.A.; Chakrabarty, N.; Hoque, A.; Islam, S.; Kabir, M.S.H.; Tareq, S.M.; Alam, A.H.M.K.; Haque, A.; et al. Curculigo recurvata W.T. Aiton exhibits anti- nociceptive and anti-diarrheal effects in Albino mice and an in silico model. Anim. Model Exp. Med. 2020, 3, 169-181. [CrossRef]

94. Cao, S.; Tian, S.; Bai, M.; Liu, S.Y.; Jia, J.J.; Miao, M.S. Effects of Curculigo orchioides total glucosides in mouse perimenopause model of related organization and organs morphology. Bangladesh J. Pharmacol. 2016, 11, S72-S81.

95. Miao, M.; Tian, S.; Guo, L.; Bai, M.; Fang, X.; Liu, S. The effect of curculigoside on mouse model of perimenopausal depression. Saudi J. Biol. Sci. 2017, 24, 1894-1902. [CrossRef] [PubMed]

96. Swaroop, A.; Preuss, H.G.; Bagchi, M.; Bagchi, D. Safety and efficacy of a novel Curculigo orchioides extract in boosting tes-tosterone levels in male rats. FASEB J. 2018, 32, 656.26. [CrossRef]

97. Bagchi, D.; Swaroop, A.; Bagchi, M.; Preuss, H.G. Safety and free testosterone boosting efficacy of a novel Curculigo orchioides extract (Blamus ${ }^{\mathrm{TM}}$ ) in male rats. FASEB J. 2017, 31, lb313. [CrossRef]

98. Chen, T.; Tu, Q.; Cheng, L.; Li, Z.; Lin, D. Effects of curculigoside A on random skin flap survival in rats. Eur. J. Pharmacol. 2018, 834, 281-287. [CrossRef] [PubMed] 